\title{
Financing Investment: The Choice between Bonds and Bank Loans *
}

\author{
Erwan Morellec $^{\dagger} \quad$ Philip Valta $\quad$ Alexei Zhdanov ${ }^{\ddagger}$
}

May 26, 2014

\begin{abstract}
We build a model of investment and financing decisions to study the choice between bonds and bank loans in a firm's marginal financing decision and its effects on corporate investment. We show that firms with more growth options, higher bargaining power in default, operating in more competitive product markets, and facing lower credit supply are more likely to issue bonds. We also demonstrate that, by changing the cost of financing, these characteristics affect the timing of investment. We test these predictions using a sample of U.S. firms and present new evidence that supports our theory.
\end{abstract}

Keywords: Debt choice; capital structure; investment; credit supply; competition.

JEL Classification Numbers: D83; G12; G32; G33.

\footnotetext{
*We thank Thomas Dangl, Laurent Frésard, Boris Nikolov, Grzegorz Pawlina (EFA discussant), Yuri Tserlukevich, Francesca Zucchi, two anonymous referees, the editor (Gustavo Manso), and seminar participants at the University of Illinois, the University of Maryland, the University of Neuchatel, the 2013 EFA meetings, and the 2014 SGF conference for useful comments. We also thank Gerard Hoberg and Gordon Phillips for making their data available. Financial support from the Swiss Finance Institute and from NCCR FINRISK of the Swiss NSF is also gratefully acknowledged. The usual disclaimer applies.

${ }^{\dagger}$ Swiss Finance Institute, EPFL, and CEPR. E-mail: erwan.morellec@epfl.ch.

${ }^{\ddagger}$ HEC Paris. E-mail: valta@hec.fr.

${ }^{\S}$ Panagora Asset Management. E-mail: zhdanov33@gmail.com.
} 
In the frictionless financial markets of Modigliani and Miller (1958), capital structure is irrelevant and all value enhancing projects can be financed. The insight that market frictions make financing decisions relevant has spawned a large body of theoretical and empirical research, most of which focuses on the choice between equity and debt. In this paper, we examine a related but much less studied topic, namely the choice between bonds and bank loans and its relation to corporate investment. To this end, we build a model of investment and financing decisions in which firms can choose not only the amount but also the type of debt to issue. We then examine whether the predictions of the model are supported by the data on firms' debt choices and investment decisions.

We base our analysis on a simple real options model in the spirit of Sundaresan and Wang (2007) or Morellec and Schürhoff (2010), in which investment and financing decisions are endogenously and jointly determined. Specifically, we consider a firm with assets in place and a growth option to expand operations. The firm is initially financed with common equity and has the possibility to exercise its growth option at any time. To finance the cost of investment, the firm can issue a mixture of equity and debt. While real options models generally assume that firms have access to a single class of debt, we consider instead that firms can finance investment using any combination of common stock, bonds, and bank loans. Our paper addresses a set of key questions in corporate finance. First, how do debt choice and capital structure (i.e. the firm's leverage ratio) interact and what are the factors that drive these interactions? Second, how do debt choice and capital structure affect investment policy? Third, how do they depend on firm characteristics?

In the model, corporate income is subject to taxation, leading to a role for debt financing. The benefits and costs of each debt source affect not only the mix of debt that borrowers demand but also corporate investment. Our theory assumes that bank loans are renegotiable so that borrowing from private lenders makes inefficient liquidations less likely and, therefore, reduces the cost of capital. However, the supply of private lenders with the required expertise is limited. Notably, one key innovation of our model is to consider that firms have to search for informed lenders when seeking 
to raise private debt, leading to financing risk and to rent extraction by private lenders. Based on these assumptions, the model characterizes the value-maximizing investment and financing policies for a firm acting in the best interests of shareholders and generates a rich set of testable predictions about the choice between bonds and bank loans and corporate investment.

We highlight the main empirical implications. First, our theory predicts that firms with valuable investment opportunities are more likely to finance investment with equity and bonds. Indeed, for such firms the hold up or rent extraction problem associated with borrowing from a private lender is particularly acute and the relative cost of private debt particularly high. Second, because bank loans are renegotiable, our model predicts that firms with lower bargaining power of shareholders in default have a preference for bank loans. Indeed, smaller deviations from absolute priority in default make renegotiable debt relatively less expensive and bank loans more attractive.

We also incorporate in our analysis several realistic factors that affect the choice between bonds and bank loans. The first such factor is the supply of capital in private credit markets. We show that credit supply has two effects on the public-private debt choice. First, it determines the likelihood of finding informed private lenders. Second, it determines their bargaining power at the time of financing and, therefore, the cost of bank loans. In particular, greater competition among financiers reduces the share of the investment surplus captured by private lenders. Therefore, a stronger supply of credit tends to push the choice of debt instrument towards bank loans.

The second factor is competition in the firm's product markets. Specifically, we consider that competitors can implement projects that will make the firm's growth option worthless and show that this risk affects the choice of debt source. Notably, as product market competition increases, the financing risk associated with bank loans increases and firms tend to favor public debt issues.

We also explore with our model how corporate investment depends on the firm and industry characteristics that determine the choice between bonds and bank loans. We find that, by changing the firm's debt structure and its cost of capital, these characteristics affect the attractiveness of 
growth options and the timing of investment. Notably, the profitability of growth options, product market competition, and private credit supply speed up investment, while the bargaining power of shareholders in default and liquidation costs delay investment.

To test the predictions of the model, we form a large sample of U.S. firms for the period 19882007. For this sample, we estimate logit models predicting the likelihood that a firm chooses bonds over bank loans. Our estimations reveal that debt choices are related to these explanatory variables in ways consistent with our theory. Notably, we find that the bargaining power of shareholders in default and the intensity of product market competition increase the likelihood of issuing public debt. We also find that firms with substantial growth opportunities are more likely to issue bonds. By contrast, firms facing a stronger credit supply are more likely to issue bank loans. The results are robust to the use of alternative proxies and to the inclusion of additional control variables.

In the second step, we identify the effects of our explanatory variables on investment rates. Specifically, we follow Whited (2006) and estimate a proportional hazard model in which we investigate which factors increase or decrease a firm's investment hazard. Our estimations show that growth options, credit supply, and competition shift investment hazard rates up, while liquidation costs and bargaining power in default shift hazard rates down, consistent with the model's predictions. We also perform several robustness tests that confirm the validity of our results.

The present paper continues a line of research that uses structural models to analyze corporate policy choices. While early studies in this literature focus either on investment or on financing decisions, ${ }^{1}$ a number of recent papers examine the relation between a firm's investment opportunity set and its capital structure, emphasizing the role of agency conflicts in the debt-equity choice. ${ }^{2}$

\footnotetext{
${ }^{1}$ See McDonald and Siegel (1985) and Leland (1994) for early contributions and Strebulaev and Whited (2012) for a review of this literature. With the exception of Hackbarth, Hennessy, and Leland (2007), that abstracts from investment decisions, financing frictions, and product market competition, these papers do not analyze the choice between public and private debt financing, which is the focus of our analysis.

${ }^{2}$ Mello and Parsons (1992) and Mauer and Triantis (1994) are the first to examine the interactions of investment and financing decisions in dynamic settings. Hennessy (2004) uses Q-theory to show that these interactions matter
} 
Among these, our work is most closely related to a set of papers that study the effects of security provisions (see Morellec, 2001, and Auh and Sundaresan, 2013) or priority structure (see Sundaresan and Wang, 2007, and Hackbarth and Mauer, 2012) on investment and financing decisions. To the best of our knowledge, however, our paper is the first that models both endogenous investment and capital structure together with the choice between bonds and bank loans. This allows us to generate additional insights and empirical predictions. Another key difference between our setup and prior contributions is the introduction of search frictions for the use of private debt. We believe that our modeling approach could be used in various other real options applications.

Second, our paper relates to the empirical literature investigating the choice between public and private debt (see Blackwell and Kidwell, 1988, Houston and James, 1996, Johnson, 1997, Krishnaswami, Spindt, and Subramaniam, 1999, Colla, Ippolito, and Li, 2012, or Lin, Ma, Malatesta, and Xuan, 2013). Our paper extends this literature in several ways. First, we use an incremental approach that analyzes the determinants of debt issues instead of focusing on the composition of a firm's debt financing at one point in time (see also Denis and Mihov, 2003, or Gomes and Phillips, 2012). This allows us to relate financing choices to explanatory variables measured just before the financing decision. Second, we provide direct evidence on the role of growth options, bargaining power of shareholders in default, credit supply, and competition in the choice of debt source. Third, we show that the determinants of the choice of debt source also affect investment rates.

Lastly, our paper relates to the study of Rajan (1992), which is the first to emphasize that while private debt can avoid inefficient liquidations, it can also lead to rent extraction. Our analysis empirically. Sundaresan and Wang (2007) and Tserlukevich (2008) propose models in which firms can issue debt to exercise a sequence of growth options. Leland (1998) studies the relation between agency costs, risk management, and dynamic capital structure choice. Chen, Miao, and Wang (2010) derive utility-maximizing investment and financing policies for risk-averse entrepreneurs. Chen and Manso (2010) examine the effects of macroeconomic fluctuations on the agency costs of debt. Hackbarth and Mauer (2012) study the relation between the priority structure of corporate debt and investment decisions. Morellec and Schürhoff $(2010,2011)$ examine the effects of personal taxation and asymmetric information on the timing of investment and the choice between debt and equity financing. 
incorporates additional determinants of debt choices, and relates debt choice to capital structure and corporate investment. This allows us to generate a rich set of empirical predictions that we test on a large sample of U.S. firms.

\section{Model and assumptions}

Throughout the paper, assets are continuously traded in complete and arbitrage-free markets. The default-free term structure is flat with an after-tax risk-free rate $r$, at which investors may lend and borrow freely. Corporate taxes are paid at a constant rate $\tau$ and full offsets of corporate losses are allowed. We consider an infinitely-lived firm with assets in place and a growth option to expand operations. Assets in place generate a continuous flow of operating income $X_{t}$ as long as the firm is in operation, where $\left(X_{t}\right)_{t \geq 0}$ is governed by the process:

$$
d X_{t}=\mu X_{t} d t+\sigma X_{t} d W_{t}, \quad X_{0}=x>0
$$

under the risk neutral probability measure $\mathcal{Q}$. In this equation, $\mu<r$ and $\sigma>0$ are constant parameters and $W=\left(W_{t}\right)_{t \geq 0}$ is a standard $\mathcal{Q}-$ Brownian motion. The firm can exercise its growth option by paying the constant investment cost $I$. Immediately upon exercise, operating income increases from $X$ to $\pi X$, where $\pi>1$ is a constant factor that determines the growth potential of the firm. The firm has flexibility in the timing of investment but it can be preempted by potential competitors if it does not invest promptly. Specifically, we assume that over each time interval $[t, t+d t]$ before investment there is a probability $\lambda d t$ that the firm loses its growth option, as in Morellec and Schürhoff (2011) or Hackbarth, Mathews, and Robinson (2012).

The firm is initially financed with equity. ${ }^{3}$ To finance investment, it can issue a mixture of debt and equity at the investment date. We consider that the firm has access to two classes of perpetual

\footnotetext{
${ }^{3}$ Extending the set-up to incorporate a mix of debt and equity does not change our results and empirical predictions. Indeed, if new debt is senior to existing debt, then investment does not affect the value of old debtholders and new debt is priced as in the current model (see Johnson and Stulz, 1985, and in Hackbarth and Mauer, 2012). If instead new debt has lower priority than existing debt, then there is debt overhang and investment is delayed by existing
} 
debt contracts: private debt contracts (i.e. bank loans) with coupon payment $b$ and public debt contracts (i.e bonds) with coupon payment $c$.

Because cash flows fluctuate stochastically, debt contracts are subject to default risk. In default, private debt contracts can be renegotiated to avoid liquidation. We assume however that private lenders with the required expertise are scarce and that, conditional on searching, the probability of getting financing from informed private creditors over each time interval $[t, t+d t]$ is $\delta d t .{ }^{4}$ We also assume that firms incur a flow cost $\phi>0$ when searching for private creditors and that, because of their scarcity, these creditors can capture part of the investment surplus at the time of financing. ${ }^{5}$

As in Rajan (1992), our theory therefore assumes that intermediaries reorganize more efficiently than public (arm's length) investors. This superior ability of private investors allows them to extract rents from borrowing firms. In our model, the source of these rents can be traced to the scarcity of informed lenders, which gives them bargaining power at the time of debt issuance. Specifically, once management and informed debt investors meet, they bargain to determine the proceeds from the debt issue or, equivalently, the allocation of the investment surplus (NPV) between shareholders and private lenders. Given a non-negative surplus $S(X ; b, c)$, we assume that the allocation of this surplus results from Nash bargaining. Denoting the bargaining power of shareholders by $\theta=\frac{\delta}{\rho+\delta}$, where $\rho \geq 0$, the amount $\omega^{*}$ that private lenders can extract satisfies

$$
\omega^{*}=\underset{\omega \geq 0}{\operatorname{argmax}} \omega^{1-\theta}[S(X ; b, c)-\omega]^{\theta}=(1-\theta) S(X ; b, c) .
$$

When $\rho=0$, we have $\theta=1$ and shareholders capture all the investment surplus. When $\rho>0$, the debt. However, because the firm invests when the cash flow shock is high, the risk of corporate debt is low at the time of investment and the effect of debt overhang on debt choices and corporate investment is limited.

${ }^{4}$ One potentially aggravating factor is that the firm may not be able to find informed private creditors with deep pockets and, thus, may have to rely on a group of private debt investors as in He and Xiong (2011).

${ }^{5}$ In the Appendix, we consider an alternative framework in which firms have access to credit lines. In this case, there are no search frictions. However, because the rate on the credit line is set ex-ante by the bank and may not reflect the financial health of the firm at the time of investment, debt will be mispriced leading to distortions in investment policy. Most of our results go through in this alternative formulation. See section 2.4 below. 
fraction of the surplus captured by shareholders increases with the supply of informed lending $\delta$. That is, competition among informed lenders reduces their ability to extract rents.

Our assumptions imply that the supply of bank loans has two effects on debt choice. First, it affects the likelihood of finding informed private lenders. Second, it affects their bargaining power at the time of issuance, and therefore, the cost of private debt. The paper does not attach any particular interpretation to the uncertainty in the supply of informed lenders. It may be related to shocks to banks health (as in Gan, 2007), to regulatory changes (as in Leary, 2009, Lemmon and Roberts, 2010, or Haselmann, Pistor, and Vig, 2010), to the limited ability of financial intermediaries to verify the viability of projects (as in Faulkender and Petersen, 2006), or to variations in monetary policy (as in Kashyap, Stein and Wilcox, 1993, or Kashyap, Lamont, and Stein, 1994).

Instead of issuing private debt, the firm can choose to issue public debt. As in Bulow and Shoven (1979) and Gertner and Scharfstein (1991), public debt contracts are not renegotiable. Therefore, public debt does not require any specific expertise and, hence, is not subject to search frictions. ${ }^{6}$ We assume however that public debt is subject to proportional issuance costs $\iota{ }^{7}$

There is recent empirical and anecdotal evidence supporting the way that we model the frictions in the private credit market and how it affects debt choice. For instance, Becker and Ivashina (2012) provide evidence suggesting that firms switch from loan to bond financing at times characterized by tight lending standards. Moreover, syndicated bank loan lending has significantly fallen in the Euro zone during the sovereign debt crisis as companies have struggled to find informed private creditors willing to provide credit. As a result, these firms have shifted towards bond issues, leading to a significant boom in the European corporate bond market. ${ }^{8}$

\footnotetext{
${ }^{6}$ Allowing public debtholders to extract part of the investment surplus would not affect our results since the value-matching condition (4) implies that there is no surplus at the time of investment with public debt.

${ }^{7}$ Blackwell and Kidwell (1988) and Krishnaswami, Spindt, and Subramaniam (1999) provide evidence that issuance costs are larger for public debt issues than for private issues.

${ }^{8}$ See, for example, Financial Times, December 2, 2012, "Eurozone syndicated loans at 10-year low", or August 14, 2012, "Debt crisis sends European blue-chips to bonds".
} 
After debt has been issued, the firm has the option to default on its debt obligations. If the firm has issued public debt at the time of investment, then default leads to liquidation. At the time of liquidation, the firm loses a fraction $\alpha \in(0,1]$ of its capital stock, leading to a drop in operating cash flows. That is, we consider that if the instant of liquidation is $T$, then $X_{T}=(1-\alpha) X_{T^{-}}$. If instead the firm has issued private debt, then default leads to renegotiation. We consider a Nash bargaining game in default that leads to a debt-equity swap, as in Fan and Sundaresan (2000). Denoting the bargaining power of shareholders in default by $\eta \in[0,1]$, the Nash bargaining solution implies that shareholders get a fraction $\eta \alpha$ of asset value in default. We assume that renegotiations may fail with probability q, as in Davydenko and Strebulaev (2007) and Favara, Schroth, and Valta (2012).

Throughout the paper, management maximizes shareholder wealth when making policy choices. For doing so, management selects $(i)$ the firm's investment policy, $(i i)$ the firm's financing structure - type of debt contract and leverage level - at the investment date, and (iii) the firm's default policy after debt has been issued. Because the decision to invest is irreversible, the firm's initial asset structure remains fixed until the firm cash flows rise to a sufficiently high level and the manager invests. Similarly, cash flows need to reach a sufficiently low level for the firm to default after investment. We can thus see the manager's policy choices as determining the coupon payment and type of debt contract issued at the time of investment, the level of the cash flow shock at which it is optimal to invest, and the level of the cash flow shock at which it is optimal to default.

\section{Model solution and empirical predictions}

\subsection{Firm value after investment}

We solve the model backwards, starting with the values of equity, private debt, and public debt after investment. We denote equity value before investment by $E_{1}(X)$ and the values of equity, bank debt, market debt, and the firm after investment by $E_{2}(X ; b, c), B(X ; b), D(X ; c)$, and $V_{2}(X ; b, c)$. In our setup, the value of equity before investment equals the sum of the present value of the 
cash flows accruing to shareholders until investment and the change in this present value at the time of investment. Since the firm can finance investment using equity and either private debt or public debt, we need to consider two cases. Suppose first that the firm issues private debt at the time of investment. In that case, shareholders get $E_{2}(X ; b, 0)-[I-B(X ; b)] \equiv V_{2}(X ; b, 0)-I$ at the time of investment and the change in equity value is given by $V_{2}(X ; b, 0)-I-E_{1}(X)$. If instead the firm issues public debt, the change in equity value at the time of investment is given by $V_{2}(X ; 0, c)-I-\iota D(X ; c)-E_{1}(X)$ where $\iota D(X ; c)$ represents issuance costs. We therefore start by computing the value of the firm after investment net of issuance costs, i.e. $V_{2}(X ; b, c)-\iota D(X ; c)$.

The value of the firm after investment is given by the sum of the cash flows accruing to claimholders until default, i.e. the after-tax operating cash flow plus the tax savings, and the present value of the cash flows accruing in default. Denote by $\underline{X}_{i}$ the default threshold selected by shareholders, for $i=B, D$ where $i=B$ (respectively $i=D$ ) when the firm issues private (respectively public) debt. Standard arguments imply that (see Appendix A):

$$
V_{2}(X ; b, c)=\pi \Lambda X+\frac{\tau\left(c 1_{i=D}+b 1_{i=B}\right)}{r}\left[1-\left(\frac{X}{\underline{X}_{i}}\right)^{\nu}\right]-\alpha\left(1_{i=D}+q 1_{i=B}\right) \pi \Lambda \underline{X}_{i}\left(\frac{X}{\underline{X}_{i}}\right)^{\nu},
$$

where $1_{i=A}=1$ if $i=A, \nu<0$ is the negative root of the quadratic equation $\frac{1}{2} \sigma^{2} y(y-1)+\mu y=r$, and the positive constant $\Lambda$ is defined by

$$
\Lambda=\frac{1-\tau}{r-\mu}
$$

This equation shows that the value of the levered firm is equal to the value of the unlevered firm (first term on the right hand side) plus the present value of the tax savings (second term) minus expected bankruptcy costs (third term). When the firm issues private debt from informed lenders, the probability of liquidation is reduced by a factor $q$ and firm value is increased.

The default threshold that maximizes equity value depends on whether the firm has issued public or private debt and is given by (see Appendix A):

$$
\underline{X}_{i}^{*}=\frac{\nu}{\nu-1} \frac{r-\mu}{\pi r}\left(c 1_{i=D}+\frac{b 1_{i=B}}{1-(1-q) \eta \alpha}\right)
$$


and the value-maximizing coupon payments for public and private debt respectively satisfy:

$$
\begin{aligned}
& c^{*}=X \Lambda \pi \frac{r(\nu-1)}{\nu(1-\tau)}\left[1-\nu-\nu(\alpha+\iota(1-\alpha)) \frac{1-\tau}{\tau-\iota}\right]^{1 / \nu}, \\
& b^{*}=X \Lambda \pi \frac{r(\nu-1)}{\nu(1-\tau)}[1-(1-q) \eta \alpha]\left[1-\nu-\frac{\nu(1-\tau) \alpha q}{(1-(1-q) \eta \alpha) \tau}\right]^{1 / \nu} .
\end{aligned}
$$

As shown by these expressions, the value-maximizing coupon payment at the time of issuance increases with the tax benefit of debt $\tau$ and decreases with bankruptcy and issuance costs $\alpha$ and $\iota$. Equation (1) also shows that when the firm issues private debt, shareholders can extract concessions from debtholders in default, leading to early default in that $\underline{X}_{B}^{*}>\underline{X}_{D}^{*}$.

Plugging these expressions in the equation for firm value and taking into account the registration costs associated with public debt contracts, we finally get the value of the levered firm at optimal leverage net of registration costs as

$$
V_{2}\left(X ; b^{*}, 0\right)=\pi \Lambda X\left\{1+\frac{\tau(\nu-1)}{\nu(1-\tau)}[1-(1-q) \eta \alpha]\left(\Theta-\Theta^{1-\nu}\right)-\alpha q \Theta^{1-\nu}\right\}
$$

and

$$
V_{2}\left(X ; 0, c^{*}\right)-\iota D\left(X ; c^{*}\right)=\pi \Lambda X\left\{1+\frac{(\tau-\iota)(\nu-1)}{\nu(1-\tau)}\left(\Gamma-\Gamma^{1-\nu}\right)-[\alpha+\iota(1-\alpha)] \Gamma^{1-\nu}\right\},
$$

where

$$
\Gamma=\left[1-\nu-\nu(\alpha+\iota(1-\alpha)) \frac{1-\tau}{\tau-\iota}\right]^{1 / \nu} \text { and } \Theta=\left[1-\nu-\frac{\nu(1-\tau) \alpha q}{(1-(1-q) \eta \alpha) \tau}\right]^{1 / \nu}
$$

In our model, the benefits of bank loans over bonds are that renegotiation in default lowers deadweight costs of financial distress and that there are no registration costs for bank loans. The cost of private debt is that informed lenders are scarce and that the possibility to renegotiate the debt contract in default leads to early default. Consistent with this tradeoff, these equations show that when there are no successful renegotiations (i.e. $q=1$ ) and no registration costs (i.e. $\iota=0)$, we have $V_{2}\left(X ; b^{*}, 0\right)=V_{2}\left(X ; 0, c^{*}\right)$. In addition, the value of the firm with private debt $V_{2}\left(X ; b^{*}, 0\right)$ decreases with renegotiation frictions $q$ while the value of the firm with public debt 
$V_{2}\left(X ; 0, c^{*}\right)$ decreases with registration costs $\iota$. Therefore, whenever $q<1$ or $\iota>0$, we have $V_{2}\left(X ; 0, c^{*}\right)<V_{2}\left(X ; b^{*}, 0\right)$. That is, one implication of the model is that there would be no place for public debt as long as the supply of bank debt was fully competitive $(\delta \uparrow \infty)$.

\subsection{Optimal investment and financing strategies}

Prior to investment, management makes two types of decisions. First, it decides on the timing of investment. Second, it decides on the financing of the capital expenditure. Since the value of the firm after investment and the surplus from investment depend on the financing strategy of the firm, the firm's investment and financing decisions have to be jointly determined.

Denote by $\bar{X}_{B}^{*}$ the level of the cash flow shock above which it is optimal to search for private debt investors and invest in the project. (Note that in contrast to standard real options models, investment may not occur at $\bar{X}_{B}^{*}$ since the firm needs to find informed lenders.) In addition, denote by $\bar{X}_{D}^{*}$ the investment threshold when financing the capital expenditure with public debt. Since firm value at the time of investment is greater when financing the project with private debt, we have $\bar{X}_{B}^{*}<\bar{X}_{D}^{*}$. That is, the value-maximizing policy for shareholders is to refrain from investing

for $X<\bar{X}_{B}^{*}$, to invest and issue private debt for $X \in\left[\bar{X}_{B}^{*}, \bar{X}_{D}^{*}\right)$ conditional on finding private debt investors, and to invest and issue public debt at $\bar{X}_{D}^{*}$ if no private debt investor has been found.

Suppose first that the cash flow shock is in the region $\left[\bar{X}_{B}^{*}, \bar{X}_{D}^{*}\right)$ where it is optimal to issue private debt at the time of investment. The total investment surplus is then given by:

$$
S\left(X, b^{*}, 0\right) \equiv V_{2}\left(X, b^{*}, 0\right)-I-E_{1}(X)=\Phi X-I-E_{1}(X)
$$

where

$$
\Phi \equiv \pi \Lambda\left\{1+\frac{\tau(\nu-1)}{\nu(1-\tau)}[1-(1-q) \eta \alpha]\left(\Theta-\Theta^{1-\nu}\right)-\alpha q \Theta^{1-\nu}\right\}>0
$$

Before investment, the firm delivers a cash flow stream $(1-\tau) X$. In addition to this cash flow stream, investors also get capital gains $\mathbb{E}\left[\mathrm{d} E_{1}\right]$ over each time interval $[t, t+d t]$. Using Itô's lemma, 
we then have that equity value before investment satisfies:

$$
\begin{aligned}
r E_{1}(X)= & \mu X E_{1}^{\prime}(X)+\frac{\sigma^{2}}{2} X^{2} E_{1}^{\prime \prime}(X)+(1-\tau) X \\
& +\lambda\left[\Lambda X-E_{1}(X)\right]+\mathbf{1}_{X \in\left[\bar{X}_{B}^{*}, \bar{X}_{D}^{*}\right)}\left[\delta \theta\left(\Phi X-I-E_{1}(X)\right)-\phi\right],
\end{aligned}
$$

where $\mathbf{1}_{X \in\left[\bar{X}_{B}^{*}, \bar{X}_{D}^{*}\right)}=1$ if $X \in\left[\bar{X}_{B}^{*}, \bar{X}_{D}^{*}\right)$.

The left hand side of this equation represents the required return for investing in the firm's equity per unit of time. The right hand side is the sum of the cash flow generated by the firm's assets and the expected change in equity value. This right hand side is similar to those derived in standard contingent claims models (see e.g. Leland, 1994). However, it contains the additional terms $\lambda\left[\Lambda X-E_{1}(X)\right]$ and $\mathbf{1}_{X \in\left[\bar{X}_{B}^{*}, \bar{X}_{D}^{*}\right)}\left[\delta \theta\left(\Phi X-I-E_{1}(X)\right)-\phi\right]$ that reflect the effects of competition and credit supply uncertainty on equity value. The second of these terms is the product of the arrival rate of an informed lender $\delta$ and the surplus that shareholders extract from investment net of search costs $\left(\theta\left(\Phi X-I-E_{1}(X)\right)-\phi\right)$, conditional on searching for informed lenders $\left(\mathbf{1}_{X \in\left[\bar{X}_{B}^{*}, \bar{X}_{D}^{*}\right)}\right)$. Similarly, the first of these terms is the product of the change in equity value when a competitor invests $\left(\Lambda X-E_{1}(X)\right)$ and the probability $\lambda$ of such an event.

Equity value is solved subject to the following boundary conditions. First, since zero is an absorbing barrier for the cash flow shock, it must be that $E_{1}(0)=0$. In that case, assets in place do not produce any cash flows and the option to expand is worthless. Also, since cash flows to claimholders are given by a (piecewise) continuous Borel-bounded function, the value function $E_{1}(\cdot)$ is piecewise $\mathcal{C}^{2}$ (see Theorem 4.9 pp. 271 in Karatzas and Shreve, 1991). Therefore, equity value satisfies the continuity and smoothness conditions:

$$
\lim _{X \downarrow \bar{X}_{B}^{*}} E_{1}(X)=\lim _{X \uparrow \bar{X}_{B}^{*}} E_{1}(X), \text { and } \lim _{X \downarrow \bar{X}_{B}^{*}} E_{1}^{\prime}(X)=\lim _{X \uparrow \bar{X}_{B}^{*}} E_{1}^{\prime}(X)
$$

where derivatives are taken with respect to $X$.

In the model, the firm can finance the capital expenditure using equity and either private debt or public debt. The value-maximizing threshold when investing with private debt satisfies the 
value-matching condition: ${ }^{9}$

$$
E_{1}\left(\bar{X}_{B}^{*}\right)=\Phi \bar{X}_{B}^{*}-I .
$$

As the cash flow shock increases it becomes more and more costly for the firm to wait for informed lenders. This gives us two additional boundary conditions. First, the value of equity at the time of investment when the firm finances the capital expenditure by issuing public debt satisfies the value-matching condition:

$$
\left.E_{1}(X)\right|_{X=\bar{X}_{D}^{*}}=V_{2}\left(\bar{X}_{D}^{*} ; 0, c^{*}\right)-\iota D\left(X_{I, D}^{*} ; c^{*}\right)-I=\Psi \bar{X}_{D}^{*}-I
$$

where

$$
\Psi \equiv \pi \Lambda\left\{1+\frac{(\nu-1)(\tau-\iota)}{\nu(1-\tau)}\left(\Gamma-\Gamma^{1-\nu}\right)-[\alpha+\iota(1-\alpha)] \Gamma^{1-\nu}\right\}
$$

Second, to ensure that investment with public debt financing occurs along the optimal path, the value of equity satisfies the smooth pasting condition:

$$
\left.\frac{\partial E_{1}(X)}{\partial X}\right|_{X=\bar{X}_{D}^{*}}=\Psi
$$

This leads to the following result (see Appendix B):

Proposition 1 The value of equity before investment is given by

$$
E_{1}(X)= \begin{cases}A X^{\xi}+\frac{1-\tau+\lambda \Lambda}{r+\lambda-\mu} X, & \text { for } X<\bar{X}_{B}^{*}, \\ C X^{\beta}+D X^{\zeta}+\frac{1-\tau+\lambda \Lambda+\delta \theta \Phi}{r+\lambda+\delta \theta-\mu} X-\frac{\delta \theta I+\phi}{r+\lambda+\delta \theta}, & \text { for } X \in\left[\bar{X}_{B}^{*}, \bar{X}_{D}^{*}\right),\end{cases}
$$

where the investment thresholds with private and public debt $\bar{X}_{B}^{*}$ and $\bar{X}_{D}^{*}$ respectively satisfy

$$
\bar{X}_{B}^{*}=z \bar{X}_{D}^{*},
$$

and

$$
\bar{X}_{D}^{*}=\frac{\frac{\zeta[(r+\lambda) I-\phi]\left(1-z^{-\beta}\right)+\xi(r+\lambda+\delta \theta) I z^{-\beta}}{(\zeta-\beta)(r+\lambda+\delta \theta)}}{\frac{\zeta-1}{\zeta-\beta} \Psi+\frac{\zeta-1}{\zeta-\beta} \frac{1-\tau+\lambda \Lambda+\delta \theta \Phi}{r+\lambda+\delta \theta-\mu}\left(z^{1-\beta}-1\right)-\frac{\zeta-\xi}{\zeta-\beta} \Phi z^{1-\beta}-\frac{\xi-1}{\zeta-\beta} \frac{1-\tau+\lambda \Lambda}{r+\lambda-\mu} z^{1-\beta}} .
$$

\footnotetext{
${ }^{9}$ This condition follows from the value matching condition of shareholders at $\bar{X}_{B}^{*}$. Optimality is ensured by the continuity and smoothness conditions.
} 
where $z<1$ is the solution to the non-linear equation

$$
\begin{aligned}
& \frac{\zeta[(r+\lambda) I-\phi]\left(1-z^{-\beta}\right)+\xi(r+\lambda+\delta \theta) I z^{-\beta}}{\beta[(r+\lambda) I-\phi]\left(z^{-\zeta}-1\right)-\xi(r+\lambda+\delta \theta) I z^{-\zeta}} \\
= & \frac{(\zeta-1)\left[\Psi+\frac{1-\tau+\lambda \Lambda+\delta \theta \Phi}{r+\lambda+\delta \theta-\mu}\left(z^{1-\beta}-1\right)\right]-(\zeta-\xi) \Phi z^{1-\beta}-(\xi-1) \frac{1-\tau+\lambda \Lambda}{r+\lambda-\mu} z^{1-\beta}}{(1-\beta)\left[\Psi+\frac{1-\tau+\lambda \Lambda+\delta \theta \Phi}{r+\lambda+\delta \theta-\mu}\left(z^{1-\zeta}-1\right)\right]-(\xi-\beta) \Phi z^{1-\zeta}+(\xi-1) \frac{1-\tau+\lambda \Lambda}{r+\lambda-\mu} z^{1-\zeta}} .
\end{aligned}
$$

In these equations, the constants $A, C$, and $D$ satisfy

$$
\begin{aligned}
A & =\left\{\left[\Phi-\frac{1-\tau+\lambda \Lambda}{r+\lambda-\mu}\right] \bar{X}_{B}^{*}-I\right\}\left(\bar{X}_{B}^{*}\right)^{-\xi}, \\
C & =\left\{\frac{\zeta-1}{\zeta-\beta}\left[\Psi-\frac{1-\tau+\lambda \Lambda+\delta \theta \Phi}{r+\lambda+\delta \theta-\mu}\right] \bar{X}_{D}^{*}-\frac{\zeta}{\zeta-\beta} \frac{(r+\lambda) I-\phi}{r+\lambda+\delta \theta}\right\}\left(\bar{X}_{D}^{*}\right)^{-\beta}, \\
D & =\left\{\frac{\beta-1}{\beta-\zeta}\left[\Psi-\frac{1-\tau+\lambda \Lambda+\delta \theta \Phi}{r+\lambda+\delta \theta-\mu}\right] \bar{X}_{D}^{*}-\frac{\beta}{\beta-\zeta} \frac{(r+\lambda) I-\phi}{r+\lambda+\delta \theta}\right\}\left(\bar{X}_{D}^{*}\right)^{-\zeta},
\end{aligned}
$$

and the constant elasticities $\xi, \beta$, and $\zeta$ are given by

$$
\begin{aligned}
& \xi=\left(\sigma^{2} / 2-\mu\right) / \sigma^{2}+\sqrt{\left[\left(\left(\sigma^{2} / 2-\mu\right) / \sigma^{2}\right]^{2}+2(r+\lambda) / \sigma^{2}\right.}>1, \\
& \beta=\left(\sigma^{2} / 2-\mu\right) / \sigma^{2}-\sqrt{\left[\left(\sigma^{2} / 2-\mu\right) / \sigma^{2}\right]^{2}+2(r+\lambda+\delta \theta) / \sigma^{2}}<0, \\
& \zeta=\left(\sigma^{2} / 2-\mu\right) / \sigma^{2}+\sqrt{\left[\left(\sigma^{2} / 2-\mu\right) / \sigma^{2}\right]^{2}+2(r+\lambda+\delta \theta) / \sigma^{2}}>1 .
\end{aligned}
$$

Equity value in Proposition 1 can be interpreted as follows. The first term on the right hand side of equity value in the no-investment region $\left(X<\bar{X}_{B}^{*}\right)$ represents the option value of investing in the project and restructuring the firm's capital structure. The second term represents the value of a perpetual claim to the current flow of income. This second term captures the effects of competition through the term $\frac{\lambda \Lambda}{r+\lambda-\mu} X$, that reflects both the increase in the discount rate due to competition and the value of the firm after a competitor has invested. Similarly, the first two terms on the right hand side of equity value in the investment with private lending region $\left(\bar{X}_{B}^{*} \leq X<\bar{X}_{D}^{*}\right)$ represent the change in the value of the firm if no private debt investor can be found before the cash flow shock returns to the no-investment region (first term) or reaches the investment threshold with public debt financing $\bar{X}_{D}^{*}$ (second term). The third term represents the sum of the present value of cash flows from assets in place and the increase in equity value due to investment with private debt financing. The fourth term represents the present value of investment and search costs. 
When the expected delay associated with private debt financing (as measured by $1 / \delta$ ) tends to zero, the value-maximizing investment threshold converges to:

$$
\lim _{\delta \uparrow \infty} \bar{X}_{B}^{*}(\delta) \equiv \bar{X}_{\infty}^{*}=\frac{\xi}{\xi-1} \frac{I}{\Phi-\Lambda} .
$$

Equation (7) for $\bar{X}_{\infty}^{*}$ can also be written as:

$$
\left\{(\pi-1)+\pi\left[\tau \frac{r(\nu-1)}{\nu(1-\tau)}[1-(1-q) \eta \alpha]\left(\Theta-\Theta^{1-\nu}\right)-\alpha q \Theta^{1-\nu}\right]\right\} \Lambda \bar{X}_{\infty}^{*}=\frac{\xi}{\xi-1} I .
$$

The left-hand side of this equation represents the benefit from investment. At the time of investment, the firm $(i)$ increases its operating cash flows (first term $\pi-1$ in the bracket) and $(i i$ ) rebalances its capital structure (second term in the bracket). The right hand side of this equation is the adjusted cost of investment. This cost reflects the option value of waiting through the factor $\frac{\xi}{\xi-1}$. When this option has no value (which is the case as $\lambda$ tends to infinity), shareholders invest as soon as the standard NPV is positive (i.e. as soon as $X>\frac{I}{\Phi-\Lambda}$ ).

\subsection{Model predictions}

The public-private debt choice. Since bank loans are renegotiable - and therefore less costly - firms find it optimal to finance investment by issuing private debt if the supply of bank loans is high enough and the pricing of private debt is competitive enough. To better understand the economic determinants of firms' financing decisions, Figure 1 plots the ratio of the investment triggers $z \equiv \frac{\bar{X}_{B}^{*}}{\bar{X}_{D}^{*}}$ as a function of the arrival rate of informed lenders $\delta$, the bargaining power of shareholders in default $\eta$, the size of the growth option $\pi$, liquidation $\operatorname{costs} \alpha$, and the arrival rate of competitors $\lambda$. In this Figure, a low value for $z$ implies that firms have a greater likelihood of financing the capital expenditure with private debt (holding $\mu$ and $\sigma$ constant).

Insert Figure 1 Here

In this Figure, the risk free rate is set to $r=5 \%$. The risk-neutral growth rate and volatility of the cash flow shock are set to $\mu=0.67 \%$ and $\sigma=28.86 \%$, in line with the estimates of Morellec, 
Nikolov, and Schürhoff (2012). The tax advantage of debt captures corporate and personal taxes and is set equal to $\tau=15 \%$. This corresponds to a tax environment in which the corporate tax rate is set at $35 \%$ and the tax rates on dividends and interest income are set to $11.6 \%$ and $29.3 \%$, consistent with Graham (1996). We base the value of liquidation costs on the estimates of Glover (2012) and set $\alpha=45 \%$. The size of the growth option is set to $\pi=1.25$ while the arrival rate of competitors is set to $\lambda=1$ so that the expected lifetime of the growth option is 1 year. We set issuance costs to $\iota=2 \%$, in line with the estimates of Altinkilic and Hansen (2000) or Kim, Palia, and Saunders (2008). Finally, we set $\delta=3$, implying an expected financing delay with private debt of $\frac{1}{\delta}=4$ months, and $\rho=0.03$, implying that $99 \%$ of the investment surplus goes to shareholders.

Figure 1 shows that as the supply of bank loans increases, the spread between the two thresholds widens. Indeed, as $\delta$ increases, the present value of potential savings in default costs increases, the pricing of private debt improves, and it becomes relatively less interesting to finance the capital expenditure by issuing public debt. In addition, Figure 1 shows that an increase in the bargaining power of shareholders in default increases the cost of bank loans and makes public debt more attractive (i.e. $z$ increases). Figure 1 also shows that as the growth option becomes more valuable (i.e. as $\pi$ increases) and as competition intensifies (i.e. as $\lambda$ increases), the wedge between the two investment thresholds decreases, implying that firms become more likely to issue bonds.

REMARK: In the model, bankruptcy costs have two opposite effects on the cost of private debt. First, they increase the renegotiation surplus. Second, they induce early default, leading to a combined effect that is difficult to sign (i.e. to a non-monotonic relation between $\alpha$ and $z$ ). By contrast, an increase in the bargaining power of shareholders in default leads to an increase in default risk and to an unambiguous increase in the cost of private debt. In the analysis below, we therefore focus on measuring the effects of this factor on the choice between bonds and bank loans.

Corporate investment. In the model, the timing of investment is endogenous and investment occurs the first time the cash flow process reaches the region $\left[\bar{X}_{B}^{*}, \bar{X}_{D}^{*}\right)$ and the firm can find private 
debt investors or reaches $\bar{X}_{D}^{*}$ before informed debt investors can be found. Table 1 examines the determinants of investment hazards, defined as the probability of undertaking the project as a function of time. To do so, we simulate a panel of $N=237,400$ firms using a procedure described in the Appendix. Given the grouped data structure of our panel, we follow Whited (2006) and Leary and Roberts (2005) and estimate a mixed proportional hazard model, for which the hazard function at time $t$ for firm $i$ with covariates $x_{i}(t)$ is

$$
\gamma_{i}(t)=\omega_{i} \gamma_{0}(t) \exp \left(x_{i}(t)^{\prime} \kappa\right)
$$

In this model, $t$ is the time to investment (or equivalently the length of a spell), $\gamma_{0}(t)$ is the baseline hazard, which we model as a non-parametric step function, and $\exp \left(x_{i}(t)^{\prime} \kappa\right)$ is the relative risk associated with the set of covariates $x_{i}(t)$, which allow the hazard to shift up or down depending on their values and on $\kappa$. Finally, $\omega_{i}$ is a random variable representing unobserved heterogeneity, which we assume to be independent of $x_{i}(t)$. The covariates that we include are the profitability of growth options, the bargaining power of shareholders in default, credit supply, competition, and liquidation costs. We estimate this model using maximum likelihood.

Consistent with economic intuition, Table 1 shows that firms with more (or more valuable) growth options or operating in more competitive environments invest more readily. Firms invest also more readily when the supply of informed lenders is stronger since the cost of capital decreases with credit supply. By contrast, liquidation costs, and the bargaining power of shareholders in default diminish investment propensities by making outside financing more costly.

Insert Table 1 Here

An additional implication of our model is that negative shocks to the supply of bank debt may hamper investment even if firms have enough financial slack to finance investment (due to the ability to issue equity costlessly), consistent with the findings in Kashyap, Stein and Wilcox (1993) and Lemmon and Roberts (2010). Indeed, in our model, investment and financing decisions are 
jointly determined and the profitability of investment depends on the financing instrument chosen by the firm. As a result, a change in the supply or in the cost of one of the financing instruments can have major effects on the timing and probability of investment.

\subsection{Summary of empirical implications}

Before turning to the empirical analysis, we summarize our main testable hypotheses:

Hypothesis 1: Debt Choice. Firms (i) with more growth options, (ii) higher bargaining power in default, (iii) operating in more competitive product markets, and (iv) facing lower credit supply are more likely to issue public debt.

Hypothesis 2: Investment. Firms with (i) high bargaining power of shareholders in default and (ii) high liquidation costs delay investment, whereas firms (iii) operating in competitive markets, (iv) facing a strong credit supply, or (v) with profitable growth options speed up investment.

To the best of our knowledge, our predictions on the effects of competition, credit supply, or bargaining power of shareholders in default on debt choice are novel. The prediction on the effects of credit supply on investment is also new to the literature. Some of our other predictions on investment timing are shared with existing studies. For example, Sundaresan and Wang (2007) show that higher bargaining power of shareholders in default delays investment. However, to the best of our knowledge, we are the first to provide evidence supporting this result. Akdogu and MacKay (2008) document a non-linear relation between investment hazards and measures of product market competition. In addition, Almeida and Campello (2008) and Chaney, Sraer, and Thesmar (2012) find that the level of investment is positively related to asset tangibility.

Our study complements that of Akdogu and MacKay by demonstrating the effects of competition on corporate investment using a new measure that has been shown to better capture competition. Similarly, while Almeida and Campello (2008) and Chaney, Sraer, and Thesmar (2012) focus on the relation between investment levels and tangibility, our analysis examines instead the effects 
of asset tangibility on the timing of large investment projects. That is, in contrast to these studies, our empirical approach allows us to capture the effects of our explanatory variables on infrequent and lumpy investment (see Doms and Dunne, 1998, or Cooper, Haltiwanger, and Power, 1999, for evidence suggesting that investment decisions are lumpy).

REMARK: We show in the Appendix that modeling private debt using credit lines produces the same results on the effects of the profitability of the growth option or volatility if the pre-committed interest rate does not depend on firm characteristics. In that case, credit lines become less attractive as the growth option becomes more valuable because the rate on the credit line does not depend on $\pi$ whereas the cost of public debt decreases with $\pi$. By contrast, the cost of public debt goes up as volatility increases while the interest rate on the credit line remains constant, making credit lines more attractive. One important difference between credit lines and search is that higher bargaining power of shareholders would lead to a more extensive use of private debt. Indeed, the rate on the line of credit is independent of $\eta$ and the value of equity increases with $\eta$, making credit lines more attractive to shareholders. Lastly, for credit supply to matter, we would need to assume that the interest rate on the credit line decreases with credit supply.

\section{Empirical analysis}

\subsection{Data and sample description}

Our empirical analysis is based on a sample of U.S. firms. We begin the sample construction by collecting data from Compustat's annual database for the period 1988-2007. Financial services firms (one-digit SIC equal to six) and regulated industries (two-digit SIC equal to 49) are excluded from the sample (see Leary and Roberts, 2005, or Whited, 2006). We also drop firm-years with negative or zero total assets or sales, and firm-years for which the negative EBITDA is larger than total assets (see Bris, Koskinen, and Nilsson, 2009). The results are robust to relaxing these constraints. 
We then merge this data set with data from various other sources. First, following Erel, Julio, Kim, and Weisbach (2012), we obtain data on public debt issues from the Mergent Fixed Income Securities Database (FISD) and data on bank debt from Loan Pricing Corporation's Dealscan database. From FISD, we use all USD public debt issues made by domestic industrial firms with a valid issuer CUSIP, offering date, offering amount, and maturity. Similarly, from Dealscan we get all sole-lender and syndicated bank loans with a valid GVKEY, loan start date, loan amount, and maturity. We only keep firms that issue at least one bond or loan during our sample period, and we eliminate $(i)$ loans that are explicitly used for repaying existing loans, and $(i i)$ very small bonds and loans as they are unlikely to be used for investment purposes. ${ }^{10}$

Next, we collect data on industry competition from the Hoberg and Phillips data library. We also retrieve institutional ownership data from Thomson Reuters' ownership database, and corporate governance data on the E-Index used in the paper by Bebchuk, Cohen, and Ferrell (2009). Finally, we get data on credit conditions from the Senior Loan Officer Opinion Survey on Bank Lending Practices from the Federal Reserve. Using these data sources, we construct the following variables.

Growth options $(\pi)$. We measure the importance of growth opportunities using the firm's sales growth as in Whited (2006), Grullon, Lyandres, and Zhdanov (2012), or Purnanandam and Rajan (2012). Sales growth is computed as the growth in sales (sale) from year $t-1$ to $t$.

Shareholders' bargaining power in default $(\eta)$. Following Davydenko and Strebulaev (2007), we measure shareholders' bargaining power in default by the fraction of total equity owned by institutional investors since more sophisticated and coordinated institutional investors are better at bargaining with creditors in potential renegotiations.

Supply of bank loans $(\delta)$. Our main proxy for the supply of bank loans (credit supply) is based on the "Senior Loan Officier Opinion Survey on Bank Lending Practices" from the Federal

\footnotetext{
${ }^{10}$ We compute the bond and loan amount to asset ratios, respectively, and drop the lowest five percent of each distribution. Keeping these observations in the sample has no impact on our results.
} 
Reserve. ${ }^{11}$ The Federal Reserve conducts this survey by asking the sixty largest banks and twentyfour U.S. branches of foreign banks how their bank is changing their credit standards. We focus on the variable "Net percentage of banks tightening standards for commercial and industrial loans to large and middle-market firms." In actual tests, we lag this variable by one quarter and multiply it by minus one so that a higher value implies a higher supply of bank loans. The data is at the quarterly frequency and only available after the second quarter of $1990 .^{12}$

Competition $(\lambda)$. Our main proxy for the intensity of competition is the product market fluidity measure developed by Hoberg, Phillips, and Prabhala (2012), available in the Hoberg and Phillips data library starting in year 1997. This proxy is based on product descriptions from firm 10-Ks and captures the structure and evolution of the product space occupied by firms. In particular, it captures competitive threats faced by firms and the changes in rivals' products relative to the firm. Liquidation costs $(\alpha)$. Following Davydenko and Strebulaev (2007), we use non-fixed assets (1net PPE (ppent)) scaled by total assets as our main liquidation cost proxy. In our estimations, we expect liquidation costs to decrease investment propensities.

We include in our estimations several control variables that have been shown to affect debt structure (see e.g. Houston and James, 1996, Johnson, 1997, Krishnaswami, Spindt, and Subramaniam, 1999, or Colla, Ippolito, and Li, 2012). We measure cash flow volatility as the annual standard deviation of cash flows over the past five years, where we require at least three consecutive observations. Size is the logarithm of net sales (sale). Market leverage is book debt over the market value of assets (market equity plus total assets minus total common equity (ceq)). A dummy variable, IG rating, takes the value of one when the firm has an investment grade rating and zero

\footnotetext{
${ }^{11}$ Several recent papers use data from this survey to capture credit supply conditions, e.g., Erel, Julio, Kim, and Weisbach (2012), Murfin (2012), or Becker and Ivashina (2012).

${ }^{12}$ In additional tests, we follow Erel, Julio, Kim, and Weisbach (2012) and use two additional proxies for the supply of bank loans. The first proxy is real GDP growth at the quarterly frequency. The second measure for the supply of bank loans is a dummy variable equal to one if the economy is in an expansion according to the NBER in a particular quarter and zero otherwise. The results using these variables are available upon request.
} 
otherwise. Finally, in our analysis of investment hazards, investment denotes capital expenditures (capx) during the fiscal year divided by total assets at the beginning of the fiscal year. We winsorize all firm-level variables at the $1 \%$ level in each tail to minimize the impact of outliers. Table 2 shows the definitions of all the variables used in the analysis.

Insert Table 2 Here

Panel A of Table 3 provides descriptive statistics of the firm characteristics. The full sample is an unbalanced panel with 49,063 firm-year observations. ${ }^{13}$ The average market-to-book ratio is 1.53 , average sales growth is $16 \%$, and the average intangibility measure is $69 \%$. The average proportion of common stock held by institutional investors is $46 \%$, a value slightly lower than the one reported by Davydenko and Strebulaev (2007). Investment has a mean value of $7.6 \%$ of lagged total assets. Firms in our sample have average log sales of 5.86, which corresponds to total sales of 350 million. Moreover, they have an average market leverage of $20 \%$, cash flow of $4.8 \%$ of assets, and cash flow volatility of $7.7 \%$, and a default probability of $18.9 \%$ (median of $0.4 \%$ ).

\section{Insert Table 3 Here}

Panel B provides descriptive statistics for the credit supply and competition variables. Over our sample period, the average net percentage of banks tightening credit standards is $6.3 \%$. Furthermore, our main proxy for competition, product market fluidity, has an average value of 6.6, which is close to the value of 6.9 reported by Hoberg, Phillips, and Prabhala (2012).

\footnotetext{
${ }^{13}$ The number of observations is lower for the debt choice analysis. The reason for the difference is that in the debt choice analysis, we use the sample firms at the monthly frequency (as Erel, Julio, Kim, and Weisbach, 2012) and only keep the firm-months in which firms actually issue at least one bond or loan. By contrast, for the investment hazard analysis, we have the same set of firms in a more traditional firm-year panel data set.
} 


\subsection{The choice between bonds and bank loans}

In this section, we test the model's predictions regarding the choice between bonds and bank loans. We collapse each firm's bond and bank loan issues at the month level and match the firm-months observations with accounting information from the most recent year-end reported in Compustat and with the quarterly macroeconomic data. We only keep the firm-months in which firms issue a bond or loan. Next, we eliminate firm-months in which firms issue both bonds and bank loans (477 observations) and drop convertible bond issues (1,812 observations). We end up with a sample containing 3,602 firm-months with bond issues (4,692 bond issues) and 10,934 firm-months with bank loan issues (15,575 loan issues).

Insert Table 4 Here

Table 4 shows descriptive statistics on how the bond and loan issues are distributed over the sample period and how they vary by firm size. The number of bond issues gradually increases at the beginning of our sample period, reaching a maximum of 463 issues in the year 1998. The number of loan issues experiences significant growth with a maximum of 1,226 loan issues in 2004 . This growth in the syndicated loan market is consistent with recent research on this topic (see, e.g., Ivashina and Scharfstein, 2010). Next, in each year, we split the number of bond and loan issues by the median size of the issuer and report the number of issues for small and large firms, respectively. As expected, bonds are predominantly issued by large firms, while small firms have a preference for loans. Finally, we note that in each year about $50 \%$ of our sample firms do not issue any bonds, while only about $5 \%$ of firms do not issue any loans.

To test the model predictions, we estimate logistic discrete choice models in which the dependent variable equals one if the firm issues public debt and zero if the firm issues private debt in a given month. In these logistic regressions, we are interested in measuring the effects of growth options, bargaining power in default, credit supply, and competition on the probability of issuing public or private debt. Following the literature, we include other potential determinants of the debt choice, 
including firm size, leverage, and credit rating (see Erel, Julio, Kim, and Weisbach, 2012, Johnson, 1997, Denis and Mihov, 2003, or Gomes and Phillips, 2012). Table 5 presents the main results.

Insert Table 5 Here

All six specifications of Table 5 examine the effects of growth options on the likelihood of issuing public debt. The coefficient is positive and statistically significant in all columns, consistent with the model's predictions. ${ }^{14}$ In column 1, for instance, the coefficient of growth options has a value of 0.297 , corresponding to a response probability of 0.20 evaluated at the mean of all covariates. The coefficient implies that a one standard deviation increase in sales growth (evaluated at the mean of all regressors) increases the response probability to 0.23 , which is a relative increase of $15 \%$.

In column 2, we add shareholders' bargaining power measured by institutional ownership as an additional regressor. The coefficient has a value of 0.917 and is statistically significant. The response probability for this coefficient is 0.228 . A one standard deviation increase in institutional ownership increases the response probability to 0.275 . The intuition is that as shareholders' bargaining power increases, shareholders are able to extract more rents from creditors in a potential renegotiation, and bank loans becomes more costly. As a consequence, a bond issue is more likely.

Next, we test in the third column whether the supply of bank loans (based on the Federal Reserve survey) affects the probability of issuing a bond. We observe a negative and statistically significant coefficient with a value of -0.708 (response probability of 0.23 ), a result consistent with the model's predictions. Intuitively, when the supply of bank loans increases, search frictions decrease and firms are relatively more likely to find informed bank financing. ${ }^{15}$

\footnotetext{
${ }^{14}$ We get very similar results to those presented in the tables when we estimate all our specifications with the market-to-book ratio as a proxy for growth options.

${ }^{15}$ If a firm issues public debt to refinance a private loan (as opposed to financing a new growth opportunity), and if the propensity to refinance a bank loan is negatively correlated with credit supply, our results could be biased towards finding an effect. However, the proportion of bond issues used to refinance existing bank debt is only $3.5 \%$ in Thomson Reuters bond issue database. We therefore believe that this issue is of minor concern in the data.
} 
Another unique prediction of our model is that firms operating in more competitive environments should rely more on public debt. ${ }^{16}$ Table 5 reveals that product market competition has a positive effect on the probability of issuing public debt. In column 4, the coefficient of competition is positive and statistically significant.

In columns 5 and 6 , we include industry fixed effects to control for broad industry effects, using the fixed industry classification (FIC) from the Hoberg and Phillips data library. The specification in column 6 is in addition estimated with random firm effects. The estimates in columns 5 and 6 are very similar to those in column 4 . Finally, the coefficient estimates of the control variables are consistent with the existing literature. Specifically, the negative coefficient of cash flow volatility (although not significant) is consistent with the idea that firms that are more likely to be inefficiently liquidated have a preference for bank loans. The positive coefficient on firm size supports Fama's (1985) argument that larger firms find it more economical to produce the information required for public securities, i.e. that issuance costs are relatively less important for these firms. In addition, firms with a higher leverage and an investment grade rating have a higher probability to issue bonds (see Erel, Julio, Kim, and Weisbach, 2012, or Denis and Mihov, 2003).

To assess the robustness of our results, we estimate a number of additional specifications in Table 6. We include additional control variables for firms' capital market access and for firms' internal corporate governance. We also include interaction terms between bargaining power and firm's default probability and between growth options and competition to shed further light on the economic channel. Finally, we add a control variable capturing pre-existing banking relationships of firms (see Bharath, Dahiya, Saunders, and Srinivasan (2011)).

One potential concern with the results so far could be that the proxy for bargaining power, the proportion of institutional ownership, also measures firms' access to the bond market and active monitoring of institutional investors. To address these concerns, we add a dividend payer

\footnotetext{
${ }^{16}$ This prediction of our model is not straightforward as more competition generally implies a higher likelihood of default (see e.g. Zhdanov, 2007, or Valta, 2012) and therefore a preference for private debt.
} 
dummy control variable in column 1 and the E-Index (see Bebchuk, Cohen, and Ferrell (2009)) as a governance control variable in column 2. The specification in column 1 now includes three widely used proxies for financing constraints (size, credit rating, and dividend payer dummy), and the results are consistent with our main results. In column 2, the addition of a governance control variable does not change our main results either.

\section{Insert Table 6 Here}

Our model also predicts that the effect of shareholders' bargaining power should be more important for firms with high default risk. We test this prediction by interacting a proxy for firm's default probability with bargaining power, where the default probability is estimated following Bharath and Shumway (2008). The coefficient of default probability is significantly negative in column 3, supporting the view that firms with high default risk prefer private debt to avoid inefficient liquidation. Importantly, the coefficient of the interaction term is positive and statistically significant, while the direct effect of bargaining power is small and statistically insignificant. These findings suggest that shareholders' bargaining power in default matters for debt choice mostly for firms with high default risk, and further corroborates the use our proxy for bargaining power.

In column 4 we test an additional prediction of our model that allows us to further differentiate our paper from existing contributions. Specifically, the model predicts that the effect of growth options is stronger in more competitive industries. The intuition is that the financing risk associated with bank lending is more severe when firms are more likely to lose their growth option to competitors. This effect pushes firms towards issuing bonds. To test this prediction, we split our competition variable into a dummy for high and low competition (at the sample median) and interact it with growth options. The estimates in column 4 reveal that the coefficients of high competition and of the interaction term are both significantly positive, while the coefficient of growth options decreases in magnitude and becomes insignificant, consistent with our model.

Column 5 further shows that the results are robust to the inclusion of a control variable capturing 
firms' banking relationships. ${ }^{17}$ Finally, in column 6 we restrict the sample to bond and loan issues around investment spikes. We follow Whited (2006) and consider that an investment spike occurs in the data if the ratio of investment to total assets is two times greater than the firm median. We then only keep bond and loan issues that were issued between three years before to one year after a spike. This sample restriction allows us to more closely tie firms' financing patterns to investment. While the sample size decreases to 1,231 , the results are similar to the results of the full sample.

\subsection{Investment hazards}

In this section, we test the implications of the model for investment timing by analyzing firms' investment rates (hazard rates) using a multivariate duration analysis (as in, e.g., Leary and Roberts, 2005, or Whited, 2006). To do so, we estimate a mixed proportional hazard model as described in equation (8), in which $t$ is the time to investment.

An investment spike occurs in the data if the ratio of investment to total assets is two times greater than the firm median. Our sample includes firms without any investment spike (censored firms) as well as firms with several spikes. Overall, we observe in our sample 5,829 investment spikes, corresponding to a fraction of $11.88 \%$ of spikes in the data. The average (uncensored) time between investment spikes (inaction spell) is 2.23 years. These values are similar to those reported by Whited (2006). The model is estimated using maximum likelihood.

Insert Table 7 Here

Table 7 presents estimates of the proportional hazard model. These estimates are shift parameters showing whether and by how much a variable moves the baseline hazard rate up or down. The estimations in Table 7 are without unobserved heterogeneity, that we introduce in Table 8. Moreover, we do not include yearly dummies because these would eliminate the variation in our

\footnotetext{
${ }^{17}$ We estimate several specifications in which we use alternative proxies for growth options, credit supply, and competition. Our results are robust to these additional proxies and are available upon request.
} 
credit supply proxies. Consistent with our model, columns 1 to 5 of Table 7 show that growth options shift hazard rates up in that the coefficient of growth options is positive and statistically significant in all columns. In addition, the effect is economically large. For instance, in column 1 the coefficient has a value of 0.339 , which implies that a one standard deviation increase in sales growth increases the investment hazard rate by $18.5 \%$ (i.e., $\exp (0.339 \times 0.50)-1)$.

One prediction of our model is that an increase of the bargaining power of shareholders in default increases the cost of financing and makes investment opportunities less attractive. As a result, firms delay investment (see also Sundaresan and Wang, 2007). In columns 2, the coefficient on bargaining power is negative and statistically significant, consistent with our theory. Specifically, a one standard deviation increase in bargaining power decreases the investment hazard rate by $4.4 \%$ (i.e., $\exp (-0.149 \times 0.29)-1)$. Our estimates also show that the coefficient of credit supply is positive and statistically significant in columns 3 to 6 . When the supply of lenders is strong, the availability of capital increases and its cost decreases. As a consequence, investment opportunities are more attractive and firms speed up investment.

Next, we observe that competitive threat shifts hazard rates up. Specifically, the coefficient of competition is positive and statistically significant in columns 4 to 6 . For instance, the coefficient in the fourth column implies that a one standard deviation increase in competition increases the investment hazard rate by $7.4 \%$. This result is consistent with the findings of Akdogu and MacKay (2008). Our analysis adds to their paper by showing that this result also obtains with the recent fluidity measure developed by Hoberg, Phillips, and Prabhala (2012).

In column 5, we add liquidation costs as an additional explanatory variable. The coefficient on liquidation costs is negative and statistically significant. Similar to shareholders' bargaining power, higher liquidation costs in default increase the cost of financing and make investment opportunities less attractive. Finally, column 6 also includes industry fixed effects. Note that the coefficients on the control variables are as expected. Firms with high cash flows invest sooner (Whited, 2006), 
while large firms and firms with volatile cash flows tend to delay investment. Taken together, the results from these proportional hazard estimations provide support for the model's predictions.

Insert Tables 8 Here

Table 8 reports robustness tests. In columns 1, 2, and 3, we respectively add a dividend payer dummy, the E-Index, and the default probability as additional control variables. In column 4, we vary the threshold for investment spikes. Finally, in columns 5 and 6 we allow for unobserved heterogeneity, which helps absorbing the cumulative effect of potentially omitted covariates. As in Whited (2006) or Leary and Roberts (2005), we assume that the unobserved heterogeneity has a normal (column 5) or gamma (column 6) distribution. In all six columns, the estimates are very similar to those reported in Table 8.

\section{Conclusion}

This paper develops a model to study the choice between bonds and bank loans in a firm's marginal financing decision and its effects on corporate investment. In the model, private debt is renegotiable and, therefore, more attractive to the firm than public debt. However, private lenders with the required expertise are scarce so that the firm faces search frictions when seeking to finance investment with private debt. In that respect, the paper takes a first step in constructing a model of corporate investment and financing decisions with capital supply effects.

Using this model, the paper shows that firms with more growth options, higher bargaining power in default, operating in more competitive product markets, and facing lower credit supply are more likely to issue bonds. It also demonstrates that firms with high liquidation costs and high bargaining power of shareholders in default delay investment, while firms operating in competitive markets, facing a strong supply of lenders, or having profitable growth options speed up investment. The paper provides supportive evidence for the predictions of the model using a large sample of U.S. firms for the period 1988-2007. 


\section{Appendix}

\section{A. Firm value after investment}

Denote by $\underline{X}_{i}$ the default threshold selected by shareholders, for $i=B, D$ where $i=B($ resp. $i=D)$ when the firm issues bank (resp. market) debt. After investment, shareholders get the cash flow stream $(1-\tau)\left(X-c 1_{i=D}-b 1_{i=B}\right) d t$ as well as the capital gains $\mathbb{E}\left[\mathrm{d} E_{2}\right]$ over each interval $d t$. Using Itô's lemma, we then have that equity value after investment satisfies:

$$
r E_{2}(X ; b, c)=\mu X E_{2}^{\prime}(X ; b, c)+\frac{\sigma^{2}}{2} X^{2} E_{2}^{\prime \prime}(X ; b, c)+(1-\tau)\left(X-c 1_{i=D}-b 1_{i=B}\right),
$$

which is solved subject to the value-matching and smooth-pasting conditions

$$
E_{2}\left(\underline{X}_{i} ; b, c\right)=(1-q) \eta \alpha 1_{i=B} \pi \Lambda \underline{X}_{i} \text {, and } E_{2}^{\prime}\left(\underline{X}_{i} ; b, c\right)=(1-q) \eta \alpha 1_{i=B} \pi \Lambda,
$$

together with the no-bubbles condition $\lim _{X \uparrow+\infty}(E(X ; b, c) / X)<+\infty$. Using standard calculations (see e.g. Leland, 1994), we have that $E_{2}(X ; b, c)$ satisfies for $X>\underline{X}_{i}$ :

$$
\begin{aligned}
E_{2}(X ; b, c)= & \pi \Lambda X-\frac{(1-\tau)\left(c 1_{i=D}+b 1_{i=B}\right)}{r} \\
& -\left[\left(1-(1-q) \eta \alpha 1_{i=B}\right) \pi \Lambda \underline{X}_{i}-\frac{(1-\tau)\left(c 1_{i=D}+b 1_{i=B}\right)}{r}\right]\left(\frac{X}{\underline{X}_{i}}\right)^{\nu}
\end{aligned}
$$

where $\nu<0$ is the negative root of $\frac{1}{2} \sigma^{2} y(y-1)+\mu y=r$ and the default threshold that maximizes equity value satisfies:

$$
\underline{X}_{i}^{*}=\frac{\nu}{\nu-1} \frac{r-\mu}{\pi r}\left(c 1_{i=D}+\frac{b 1_{i=B}}{1-(1-q) \eta \alpha}\right) \text { for } i=B, D .
$$

Using similar steps, we can derive the values of bank and market debt as: ${ }^{18}$

$$
\begin{aligned}
B(X ; b) & =\frac{b}{r}+\left[(1-q \alpha-(1-q) \eta \alpha) \pi \Lambda \underline{X}_{i}-\frac{c}{r}\right]\left(\frac{X}{\underline{X}_{B}}\right)^{\nu} \\
D(X ; c) & =\frac{c}{r}+\left[(1-\alpha) \pi \Lambda \underline{X}_{i}-\frac{c}{r}\right]\left(\frac{X}{X_{D}}\right)^{\nu} .
\end{aligned}
$$

The first order conditions with respect to $b$ and $c$ are given by

$$
\frac{\partial V_{2}(X ; b, 0)}{\partial b}=0, \text { and } \frac{\partial\left[V_{2}(X ; 0, c)-\iota D(X ; c)\right]}{\partial c}=0,
$$

where $V_{2}(X ; b, c)=E_{2}(X ; b, c)+B(X ; b)+D(X ; c)$. The solutions to these first order conditions are given by equations (2) and (3) (one can easily check that the second order condition for this optimization problem is negative, ensuring optimality). Plugging the expressions for the value maximizing coupon payments and default thresholds in $V_{2}(X ; b, c)-\iota D(X ; c)$ and simplifying yields the expressions reported in the main text.

\section{B. Value before investment}

The value of equity before investment satisfies

$$
\begin{array}{ll}
(r+\lambda) E_{1}(X)=\left(\mathcal{L} E_{1}\right)(X)+(1-\tau+\lambda \Lambda) X, & X<\bar{X}_{B}^{*}, \\
(r+\lambda+\delta \theta) E_{1}(X)=\left(\mathcal{L} E_{1}\right)(X)+(1-\tau+\lambda \Lambda+\delta \theta \Phi) X-\delta \theta I-\phi, & X \in\left[\bar{X}_{B}^{*}, \bar{X}_{D}^{*}\right) .
\end{array}
$$

\footnotetext{
${ }^{18}$ In the model, the private debt contract has positive NPV. Indeed, private debtholders get a claim with value given by $B(X ; b)$ plus a fraction $1-\theta$ of the investment surplus. The NPV of the private debt contract is therefore zero when $\theta=1$. Otherwise, it is equal to the fraction of the investment surplus captured by private debtholders.
} 
The general solution to this set of equations is

$$
E_{1}(X)= \begin{cases}A X^{\xi}+B X^{\vartheta}+\frac{1-\tau+\lambda \Lambda}{r+\lambda-\mu} X, & \text { for } X<\bar{X}_{B}^{*}, \\ C X^{\beta}+D X^{\zeta}+\frac{1-\tau+\lambda \Lambda+\delta \theta \Phi}{r+\lambda+\delta \theta-\mu} X-\frac{\delta \theta I+\phi}{r+\lambda+\delta \theta}, & \text { for } \in\left[\bar{X}_{B}^{*}, \bar{X}_{D}^{*}\right),\end{cases}
$$

where $A, B, C, D$ are constant parameters, $\xi>1, \zeta>1$ and $\beta<0$ are defined in Proposition 1, and $\vartheta<0$. The condition $E_{1}(0)=0$ implies that $B=0$. Simple algebraic manipulations of the other boundary conditions yield

$$
\begin{aligned}
A & =\left\{\left[\Phi-\frac{1-\tau+\lambda \Lambda}{r+\lambda-\mu}\right] \bar{X}_{B}^{*}-I\right\}\left(\bar{X}_{B}^{*}\right)^{-\xi}, \\
C & =\left\{\frac{\zeta-1}{\zeta-\beta}[\Psi-\Sigma] \bar{X}_{D}^{*}-\frac{\zeta}{\zeta-\beta} \frac{(r+\lambda) I-\phi}{r+\lambda+\delta \theta}\right\}\left(\bar{X}_{D}^{*}\right)^{-\beta}, \\
D & =\left\{\frac{\beta-1}{\beta-\zeta}[\Psi-\Sigma] \bar{X}_{D}^{*}-\frac{\beta}{\beta-\zeta} \frac{(r+\lambda) I-\phi}{r+\lambda+\delta \theta}\right\}\left(\bar{X}_{D}^{*}\right)^{-\zeta}, \\
C & =\left\{\left[\frac{\zeta-\xi}{\zeta-\beta} \Phi+\frac{\xi-1}{\zeta-\beta} \frac{1-\tau+\lambda \Lambda}{r+\lambda-\mu}-\frac{\zeta-1}{\zeta-\beta} \Sigma\right] \bar{X}_{B}^{*}-\frac{\zeta(r+\lambda) I-\zeta \phi-\xi(r+\lambda+\delta \theta) I}{(\zeta-\beta)(r+\lambda+\delta \theta)}\right\}\left(\bar{X}_{B}^{*}\right)^{-\beta}, \\
D & =\left\{\left[\frac{\xi-\beta}{\zeta-\beta} \Phi-\frac{\xi-1}{\zeta-\beta} \frac{1-\tau+\lambda \Lambda}{r+\lambda-\mu}+\frac{\beta-1}{\zeta-\beta} \Sigma\right] \bar{X}_{B}^{*}-\frac{\xi(r+\lambda+\delta \theta) I-\beta(r+\lambda) I+\beta \phi}{(\zeta-\beta)(r+\lambda+\delta \theta)}\right\}\left(\bar{X}_{B}^{*}\right)^{-\zeta} .
\end{aligned}
$$

where $\Sigma=\frac{1-\tau+\lambda \Lambda+\delta \theta \Phi}{r+\lambda+\delta \theta-\mu}$. Define $z=\bar{X}_{B}^{*} / \bar{X}_{D}^{*}<1$. Using the two equations for $C$ and $D$, one can show that:

$$
\bar{X}_{D}^{*}=\frac{\frac{\zeta[(r+\lambda) I-\phi]\left(1-z^{-\beta}\right)+\xi(r+\lambda+\delta \theta) I z^{-\beta}}{(\zeta-\beta)(r+\lambda+\delta \theta)}}{\frac{\zeta-1}{\zeta-\beta} \Psi+\frac{\zeta-1}{\zeta-\beta} \frac{1-\tau+\lambda \Lambda+\delta \theta \Phi}{r+\lambda+\delta \theta-\mu}\left(z^{1-\beta}-1\right)-\frac{\zeta-\xi}{\zeta-\beta} \Phi z^{1-\beta}-\frac{\xi-1}{\zeta-\beta} \frac{1-\tau+\lambda \Lambda}{r+\lambda-\mu} z^{1-\beta}},
$$

and

$$
\bar{X}_{D}^{*}=\frac{\frac{\beta[(r+\lambda) I-\phi]\left(z^{-\zeta}-1\right)-\xi(r+\lambda+\delta \theta) I z^{-\zeta}}{(\zeta-\beta)(r+\lambda+\delta \theta)}}{\frac{1-\beta}{\zeta-\beta} \Psi+\frac{1-\beta}{\zeta-\beta} \frac{1-\tau+\lambda \Lambda+\delta \theta \Phi}{r+\lambda+\delta \theta-\mu}\left(z^{1-\zeta}-1\right)-\frac{\xi-\beta}{\zeta-\beta} \Phi z^{1-\zeta}+\frac{\xi-1}{\zeta-\beta} \frac{1-\tau+\lambda \Lambda}{r+\lambda-\mu} z^{1-\zeta}} .
$$

Using these two equations, we then have that $z$ is the solution to equation (6).

\section{Simulation procedure}

Our analysis of the determinants of investment hazards and financing choices is based on a panel of simulated firms (as in Strebulaev, 2007, or Morellec and Schürhoff, 2011). We assume that the economy consists of a large number of firms. Each firm $i$ is characterized by the model parameters $(\sigma, \mu, \alpha, \tau, \eta, \theta, \iota, \delta, \lambda, \pi)$, which may be firm- or industry-specific. We use the parameter values of Figure 1 in our base case environment. The variables that determine investment and financing strategies in our setting are the firms' growth potential (as measured by $\pi$ ), the bargaining power of shareholders in default $\eta$, liquidation $\operatorname{costs} \alpha$, cash flow volatility $\sigma$, credit supply $\delta$, and product market competition $\lambda$. We introduce variation across firms by drawing for each firm separate parameters from their natural domains. As in Morellec and Schürhoff (2011), we opt for perturbations of the base parametrization in Figures 1 and 2. That is, we start with the base parametrization $\delta=3, \lambda=1, \sigma=0.2886, \alpha=0.45, \eta=0.5$, and $\pi=1.25$ and draw each of the parameters from uniform distributions with the same bounds as in Figure 1 while keeping the other parameters fixed. We simulate a total of $N=237,400$ firms. 


\section{Credit lines}

So far we have ignored the role of credit lines in liquidity or credit supply management. ${ }^{19}$ A firm that obtains a line of credit receives a nominal amount of debt capacity against which it can draw funds. The used portion of a line of credit is a debt obligation, whereas the unused portion remains off the balance sheet. The pricing of credit lines is generally characterized by two components: a commitment fee and a precommitted interest rate (see Sufi, 2009). The commitment fee represents a percentage of the unused portion of the line of credit. The precommitted interest rate is the rate at which firms can draw funds from the credit line. In the analysis below, we denote the size of the credit line by $\ell>0$, the precommitted interest rate by $r^{\ell}$, and assume that there is no commitment fee.

The firm can use common stock and either credit lines or public debt to finance the capital expenditure. Since there is no credit supply uncertainty, the firm will use the cheapest source of funds at the time of investment, i.e. that associated with the highest equity value. The benefit of using the credit line in this context is that the debt is private and renegotiable. The costs of using the credit line are represented by the pre-committed interest rate and by the investment distortions induced by this pre-commitment. That is, because the pre-committed rate of interest on the credit line does not depend on the timing of investment, debt will be either overpriced or underpriced leading to distortions in investment policy.

Suppose that, at the time of investment, the capital expenditure is financed by using the line of credit and common stock (if $\ell<I$ ) so that total payment to debtholders after investment is $r^{\ell} \ell$. Using similar steps as above, it is possible to show that equity value after investment when using a credit line, denoted by $E_{2}(X ; \ell)$, satisfies

$$
E_{2}(X ; \ell)=\pi \Lambda X-\frac{1-\tau}{r} r^{\ell} \ell-\frac{(1-\tau) r^{\ell} \ell}{r(\nu-1)}\left(\frac{X}{\underline{X}_{2, \ell}}\right)^{\nu}
$$

where the default threshold after investment, denoted by $\underline{X}_{2, \ell}$, satisfies

$$
\underline{X}_{2, \ell}=\frac{\nu}{\nu-1} \frac{r-\mu}{\pi r} \frac{r^{\ell} \ell}{1-(1-q) \eta \alpha}
$$

where $\nu<0$ is the negative root of the quadratic equation $\frac{1}{2} \sigma^{2} y(y-1)+\mu y=r$. Note that since $r^{\ell}$ is independent of $\eta$, credit lines become more attractive as $\eta$ increases. The value of equity before investment is then given by

$$
E_{1}(X ; \ell)=\frac{1-\tau+\lambda}{r+\lambda-\mu} X+\left[E_{2}\left(\bar{X}_{C}^{*}(\ell) ; \ell\right)-(I-\ell)-\frac{1-\tau+\lambda}{r+\lambda-\mu} \bar{X}_{C}^{*}(\ell)\right]\left(\frac{X}{\bar{X}_{C}^{*}(\ell)}\right)^{\xi}
$$

where the value maximizing investment trigger $\bar{X}_{C}^{*}$ solves

$$
\frac{\xi}{\xi-1}\left[\frac{1-\tau}{r} r^{\ell} \ell+I-\ell\right]=\left(\pi \Lambda-\frac{1-\tau+\lambda}{r+\lambda-\mu}\right) \bar{X}_{C}^{*}(\ell)-\frac{\xi-\nu}{\xi-1} \frac{(1-\tau) r^{\ell} \ell}{r(\nu-1)}\left[\left(\frac{\nu-1}{\nu} \frac{\pi r}{r-\mu} \frac{1-(1-q) \eta \alpha}{r^{\ell} \ell}\right) \bar{X}_{C}^{*}(\ell)\right]^{\nu} .
$$

Suppose next that the firm issues public debt instead of using credit lines. In this case, the value of equity before investment is given by

$$
E_{1}\left(X ; c^{*}\right)=\frac{1-\tau+\lambda}{r+\lambda-\mu} X+\left[V_{2}\left(\bar{X}_{D}^{*} ; 0, c^{*}\right)-\iota D\left(\bar{X}_{D}^{*} ; c^{*}\right)-I-\frac{1-\tau+\lambda}{r+\lambda-\mu} \bar{X}_{D}^{*}\right]\left(\frac{X}{\bar{X}_{D}^{*}}\right)^{\vartheta}
$$

where the value maximizing investment trigger satisfies

$$
\bar{X}_{D}^{*}=\frac{\xi}{\xi-1} \frac{I}{\pi \Lambda\left\{1+\frac{(\tau-\iota)(\nu-1)}{\nu(1-\tau)}\left(\Gamma-\Gamma^{1-\nu}\right)-[\alpha+\iota(1-\alpha)] \Gamma^{1-\nu}\right\}-\frac{1-\tau+\lambda}{r+\lambda-\mu}} .
$$

\footnotetext{
${ }^{19}$ We than an anonymous referee for suggesting this extension of the model.
} 
To examine the effects of the parameters of the model on the choice between credit lines and public debt, the top four panels of Figure 2 plot the relative value of equity, defined as the value of equity when using public debt over the value of equity when using a credit line (i.e. $\left.\frac{E_{1}\left(X ; c^{*}\right)}{E_{1}\left(X ; \ell^{*}\right)}\right)$, as a function of the profitability of the growth option $\pi$, the volatility of cash flows $\sigma$, the bargaining power of shareholders in default $\eta$, and bankruptcy $\operatorname{costs} \alpha$. In this figure, we assume that the firm picks $\ell^{*} \geq 0$ to maximize shareholder wealth at time $t=0$, given $r^{\ell}$. A value above 1 implies that shareholders are better off financing the investment project using a combination of common stock and public debt. Input parameter values are set as in the base case environment. The parameters for the line of credit are based on a recent empirical study by Sufi (2009). In this study, Sufi finds that the median precommitted interest rate is 150 basis points above LIBOR, i.e. $r^{\ell}=r+1.5 \%$, in a sample of 11,578 credit lines obtained by 4,011 public firms between 1996 and 2003. (Campello et al., 2012, report similar numbers in a recent survey of 800 CFOs from North America, Europe, and Asia.) For this value of the pre-committed interest rate, we have to raise the corporate tax rate to $\tau=30 \%$ for the firm to use credit lines at all.

Insert Figure 2 Here

Figure 2 reveals that in our base case environment, the value of equity with a credit line is almost always dominated by the value without a credit line. That is, we find that the costs induced by the pre-determined interest rate impose larger costs than the issuance costs of public debt in most economic environments. In our base case environment for example the credit spread on public debt at the time of issuance is 97 basis points, which is much lower than the 150 basis points of credit lines. ${ }^{20}$ As the value of the growth option increases, the credit line becomes more and more mispriced, leading to a increase in the relative value of equity. By contrast, as cash flow volatility or bankruptcy costs increase, public debt becomes more expensive and credit lines more attractive. Lastly, as the bargaining power of shareholders increases, their cash flow in default increases, rendering credit lines more attractive.

One important aspect that our analysis does not capture is the funding risk associated with sources of debt other than credit lines. The empirical literature on lines of credit argues that they are motivated primarily by capital market frictions and that a committed line of credit overcomes these frictions by ensuring that funds are available for valuable investment projects. Interestingly, the model also allows us to examine the choice between a credit line and search when choosing to issue private debt, i.e. assuming that public debt is not available. To do so, we can use the same steps as in the main text and replace the boundary conditions for equity value with public debt financing (i.e. equations (4) and (5)) by the following conditions:

$$
\begin{aligned}
& E_{1}\left(\bar{X}_{1, \ell} ; \ell\right)=E_{2}\left(\bar{X}_{1, \ell} ; \ell\right)-(I-\ell) \\
& E_{1}^{\prime}\left(\bar{X}_{1, \ell} ; \ell\right)=E_{2}^{\prime}\left(\bar{X}_{1, \ell} ; \ell\right)
\end{aligned}
$$

where $\bar{X}_{1, \ell}$ is the investment threshold when financing the project with a credit line.

The bottom two panels of Figure 2 plot the investment thresholds selected by the firm as a function of the arrival rate of investors $\delta$ and the bargaining power of creditors at the time of investment $\rho$. The figure shows that when the arrival rate of investors is very low, firms may find it optimal to use credit lines as a risk management instrument (i.e. as a hedge against a contraction in the supply of credit). This result is consistent with the evidence in Campello et al. (2012). In particular, they find that firms with more positive investment projects only use credit lines when immediate access to external funds is difficult (i.e. when $\delta$ is low). These authors write "the high proportion of funds being drawn from outstanding lines of credit during the crisis is consistent with a story where alternative sources of liquidity were unavailable." Another implication of Figure 2 is that credit lines become more attractive as the bargaining power of shareholders decreases, i.e. as the cost of debt in subsequent issues increases (due to the limited competition or supply of capital in the debt markets).

\footnotetext{
${ }^{20}$ Note also that if we take all credit lines (Revolver/Line $\geq 1$.Yr) in Dealscan from 1988 to 2007, the average spread over LIBOR is 190 basis points (with median 175). By contrast, the average treasury spread (the difference between the yield on the bond and a treasury bond with corresponding maturity) for all bonds in the FISD database over the same time period is only 98 basis points (with median 59), consistent with the numbers in our model.
} 


\section{References}

Akdogu, E., and P. MacKay, 2008, "Investment and Competition," Journal of Financial and Quantitative Analysis 43, 299-330.

Almeida, H., and M. Campello, 2007, "Financial Constraints, Asset Tangibility, and Corporate Investment," Review of Financial Studies 20, 1429-1460.

Altinkilic, Oya, and Robert S. Hansen, 2000, Are There Economies of Scale in Underwriting Fees: Evidence of Rising External Financing Costs, Review of Financial Studies 13, 191-218.

Auh, J.K., and S. Sundaresan, 2013, "Bankruptcy Code, Optimal Liability Structure, and Secured ShortTerm Debt," Working Paper, Columbia University.

Barclay, M., and C. Smith, 1995, "The Maturity Structure of Corporate Liabilities," Journal of Finance $50,609-631$.

Bebchuk, L., A. Cohen, and A. Ferrell, 2009, "What Matters in Corporate Governance?," Review of Financial Studies 22, 783-827.

Becker, B., 2007, "Geographical Segmentation of US Capital Markets," Journal of Financial Economics $85,151-178$.

Becker, B. and V. Ivashina, 2012, "Cyclicality of Credit Supply: Firm Level Evidence," Working Paper, Harvard Business School.

Berger, P., E. Ofek, and I. Swary, 1996, "Investor Valuation and the Abandonment Option," Journal of Financial Economics 42, 257-287.

Bharath, S., S. Dahiya, A. Saunders, and A. Srinivasan, 2011, "Lending Relationships and Loan Contract Terms," Review of Financial Studies 24, 1141-1203.

Bharath, S., and T. Shumway, 2008, "Forecasing Default with the Merton Distance to Default Model," Review of Financial Studies 21, 1339-1369.

Blackwell, D., and D. Kidwell, 1988, "An Investigation of Cost Differences between Public Sales and Private Placements of Debt," Journal of Financial Economics 22, 253-278.

Bris, A., Y. Koskinen, and M. Nilsson, 2009, "The Euro and Corporate Valuations," Review of Financial Studies 22, 3171-3209.

Bullow, J. and J. Shoven, 1978, "The Bankruptcy Decision," Bell Journal of Economics 9, 436-445.

Campello, M., E. Giambona, J. Graham, and C. Harvey, 2012, "Access to Liquidity and Corporate Investment in Europe During the Financial Crisis," Review of Finance 16, 323-346.

Chaney, T., D. Sraer, and D. Thesmar, 2012, "The Collateral Channel: How Real Estate Shocks Affect Corporate Investment," American Economic Review Forthcoming.

Chen, H., and G. Manso, 2010, "Macroeconomic Risk and Debt Overhang," Working Paper, MIT.

Colla, P., F. Ippolito, and K. Li, 2012, "Debt Specialization," Journal of Finance forthcoming.

Cooper, R., J. Haltiwanger, and L. Power, 1999, "Machine Replacement and the Business Cycle: Lumps and Bumps," American Economic Review 89, 921-946.

Davydenko, S., and I. Strebulaev, 2007, "Strategic Actions and Credit Spreads: An Empirical Investigation," Journal of Finance 62, 2633-2671. 
Denis, D. and V. Mihov, 2003, "The choice among bank debt, non-bank private debt, and public debt: Evidence from new corporate borrowings," Journal of Financial Economics 70, 3-28.

Doms, M., and T. Dunne, 1998, "Capital Adjustment Patterns in Manufacturing Plants," Review of Economic Dynamics 1, 409-429.

Erel, I., B. Julio, W. Kim, and M. Weisbach, 2012, "Macroeconomic Conditions and Capital Raising," Review of Financial Studies 25, 341-376.

Fama, E., 1985, "What's Different about Banks?," Journal of Monetary Economics 15, 29-37.

Fan, H., and S. Sundaresan, 2000, "Debt Valuation, Renegotiation, and Optimal Dividend Policy," Review of Financial Studies 13, 1057-1099.

Faulkender, M., and M. Petersen, 2006, "Does the Source of Capital Affect Capital Structure," Review of Financial Studies 19, 45-79.

Favara, G., E. Schroth, and P. Valta, 2012, "Strategic Default and Equity Risk Across Countries," Journal of Finance 67, 2051-2095.

Gan, J., 2007, "The Real Effects of Asset Market Bubbles: Loan- and Firm-Level Evidence of a Lending Channel," Review of Financial Studies 20, 1941-1973.

Gertner, R., and D. Scharfstein, 1991, "A Theory of Workouts and the Effects of Reorganization Law," Journal of Finance 46, 1189-1222.

Glover, B., 2011, "The Expected Cost of Default," Working Paper, Carnegie Mellon University.

Gomes, A., and G. Phillips, 2012, "Why do firms issue private and public securities?," Journal of Financial Intermediation 21, 619-658.

Graham, J., 1996, "Debt and the Marginal Tax Rate," Journal of Financial Economics 41, 41-73.

Graham, J., and C. Harvey, 2001, "The Theory and Practice of Corporate Finance: Evidence from the Field," Journal of Financial Economics 60, 187-243.

Grullon, G., E. Lyandres, and A. Zhdanov, 2012, "Real Options, Volatility and Stock Returns," Journal of Finance forthcoming.

Hackbarth, D., C. Hennessy, and H. Leland, 2007, "Can the Tradeoff Theory Explain Debt Structure?" Review of Financial Studies 20, 1389-1428.

Hackbarth, D., R. Mathews, and D. Robinson, 2012, "Capital Structure, Product Market Dynamics, and the Boundaries of the Firm," Working Paper, University of Illinois.

Hackbarth, D., and D. Mauer, 2012, "Optimal Priority Structure, Capital Structure, and Investment," Review of Financial Studies 25, 747-796.

Haselmann, R., K. Pistor, and V. Vig, 2010, "How Law Affects Lending," Review of Financial Studies 23, 549-580.

He, Z., and W. Xiong, 2012, "Dynamic Debt Runs," Review of Financial Studies 25, 1799-1843.

Hennessy, C., 2004, "Tobin's Q, Debt Overhang, and Investment," Journal of Finance 59, 1717-1742.

Hoberg, G., and G. Phillips, 2010, "Product Market Synergies and Competition in Mergers and Acquisitions: A Text-Based Analysis," Review of Financial Studies 23, 3773-3811.

Hoberg, G., and G. Phillips, 2011, "Text-Based Network Industries and Endogenous Product Differentiation," Working Paper, University of Maryland. 
Hoberg, G., G. Phillips, and N. Prabhala, 2012, "Product Market Threats, Payouts, and Financial Flexibility," Journal of Finance Forthcoming.

Houston, J., and C. James, 1996, "Bank Information Monopolies and the Mix of Private and Public Debt Claims," Journal of Finance 51, 1863-1889.

Hou, K., and D. Robinson, 2006, "Industry Concentration and Average Stock Returns," Journal of Finance 61, 1927-1956.

Ivashina, V., and D. Scharfstein, 2010, "Bank Lending during the Financial Crisis of 2008," Journal of Financial Economics 97, 319-338.

Johnson, S., 1997, "An Empirical Analysis of the Determinants of Corporate Debt Ownership Structure," Journal of Financial and Quantitative Analysis 32, 47-69.

Johnson, H, and R. Stulz, 1985, "An Analysis of Secured Debt", Journal of Financial Economics 14, 501-521.

Karatzas, I., and S. Shreve, 1991, Brownian Motion and Stochastic Calculus, Springer Verlag.

Kashyap, A., O. Lamont, and J. Stein, 1994, "Credit Conditions and the Cyclical Behavior of Inventories," Quarterly Journal of Economics 109, 565-592.

Kashyap, A., J. Stein, and D. Wilcox, 1993, "Monetary Policy and Credit Conditions: Evidence from the Composition of External Finance," American Economic Review 83, 78-98.

Kim, Dongcheol, Darius Palia, and Anthony Saunders, 2008, The Impact of Commercial Banks on Underwriting Spreads: Evidence from Three Decades, Journal of Financial and Quantitative Analysis 43, 975-1000.

Krishnaswami, S., P. Spindt, and V. Subramaniam, 1999, "Information Asymmetry, Monitoring, and the Placement Structure of Debt," Journal of Financial Economics 51, 407-434.

Leary, M., 2009, "Bank Loan Supply, Lender Choice, and Corporate Capital Structure," Journal of Finance 64, 1143-1185.

Leary, M., and M. Roberts, 2010, "The Pecking Order, Debt Capacity, and Information Asymmetry," Journal of Financial Economics 95, 332-355.

Leary, M., and M. Roberts, 2005, "Do Firms Rebalance Their Capital Structures?," Journal of Finance $60,2575-2619$

Leland, H., 1994, "Corporate Debt Value, Bond Covenants, and Optimal Capital Structure," Journal of Finance 49, 1213-1252.

Leland H., 1998, "Agency Costs, Risk Management, and Capital Structure," Journal of Finance 53, 12131243.

Lemmon, M., and M. Roberts, 2010, "The Response of Financing and Investment to Changes in the Supply of Credit," Journal of Financial and Quantitative Analysis 45, 555-587.

Lin, C., Y. Ma, P. Malatesta, and Y. Xuan, 2013, "Corporate Ownership Structure and the Choice Between Bank Debt and Public Debt," Journal of Financial Economics Forthcoming.

Mauer, D., and A. Triantis, 1994, "Interactions of Corporate Financing and Investment Decisions: A Dynamic Framework," Journal of Finance 49, 1253-1277.

McDonald, R., Siegel, J., 1986, "The value of waiting to invest," Quarterly Journal of Economics 101, 707-728. 
Mello, A., and J. Parsons, 1992, "Measuring the Agency Cost of Debt," Journal of Finance 47, 1887-1904.

Modigliani, F., and M. Miller, 1958, "The Cost of Capital, Corporation Finance, and the Theory of Investment", American Economic Review 48, 261-297.

Morellec, E., 2001, "Asset Liquidity, Capital Structure and Secured Debt," Journal of Financial Economics 61, 173-206.

Morellec, E., B. Nikolov, and N. Schürhoff, 2012, "Corporate Governance and Capital Structure Dynamics," Journal of Finance 67, 803-844.

Morellec, E., and N. Schürhoff, 2010, "Dynamic Investment and Financing under Personal Taxation," Review of Financial Studies 23, 101-146.

Morellec, E., and N. Schürhoff, 2011, "Corporate Investment and Financing under Asymmetric Information," Journal of Financial Economics 99, 262-288.

Murfin, J., 2012, "The Supply-Side Determinants of Loan Contract Strictness" Journal of Finance 67, $1565-1601$.

Purnanandam, A., and U. Rajan, 2012, "Growth Option Exercise and Capital Structure," Working Paper, University of Michigan.

Rajan, R., 1992, "Insiders and Outsiders: The Choice between Informed and Arm's Length Debt," Journal of Finance 47, 1367-1400.

Strebulaev, I., 2007, "Do Tests of Capital Structure Mean What They Say?" Journal of Finance 62, 17471787.

Strebulaev, I., and T. Whited, 2012, "Dynamic Models and Structural Estimation in Corporate Finance," Working Paper, Stanford University.

Strebulaev, I., H. Zhu, and P. Zryomov, 2012, "Dynamic Information Asymmetry, Financing, and Investment," Working Paper, Stanford University.

Sufi, A., 2009, "Bank Lines of Credit in Corporate Finance: An Empirical Analysis," Review of Financial Studies 22, 1057-1088.

Sundaresan, S., and N. Wang, 2007, "Investment Under Uncertainty with Strategic Debt Service," American Economic Review 97, 256-261.

Sundaresan, S., and N. Wang, 2006, "Dynamic investment, Capital Structure, and Debt Overhang," Working Paper, Columbia University.

Tirole, J., 1988, The Theory of Industrial Organization, MIT Press.

Tserlukevich, Y., 2008, "Can Real Options Explain Financing Behavior?" Journal of Financial Economics $89,232-252$.

Valta, P., 2012, "Competition and the Cost of Debt" Journal of Financial Economics 105, 661-682.

Whited, T., 2006, "External Finance Constraints and the Intertemporal Pattern of Intermittent Investment," Journal of Financial Economics 81, 467-502.

Zhdanov, A., 2007, "Competitive Equilibrium with Debt" Journal of Financial and Quantitative Analysis 42, 709-734. 
Table 1

Investment hazard model estimates: Simulated data

Table 1 reports estimates from semi-parametric investment hazard models on simulated data. The independent variables are the profitability of growth options $\pi$, liquidation costs $\alpha$, shareholders' bargaining power in default $\eta$, the arrival rate of informed lenders $\delta$, and the arrival rate of competitors $\lambda$. The symbol $* * *$ indicates statistical significance at the $1 \%$ level.

\begin{tabular}{lccccc}
\hline & $(1)$ & $(2)$ & $(3)$ & $(4)$ & $(5)$ \\
\hline Growth options & $1.103^{* * *}$ & $1.104^{* * *}$ & $1.105^{* * *}$ & $1.105^{* * *}$ & $1.106^{* * *}$ \\
Liquidation costs & $(0.010)$ & $(0.010)$ & $(0.010)$ & $(0.010)$ & $(0.010)$ \\
& & $-0.387^{* * *}$ & $-0.411^{* * *}$ & $-0.412^{* * *}$ & $-0.413^{* * *}$ \\
Bargaining power in default & & $(0.020)$ & $(0.021)$ & $(0.021)$ & $(0.021)$ \\
& & & $-0.229^{* * *}$ & $-0.229^{* * *}$ & $-0.230^{* * *}$ \\
Credit supply & & $(0.010)$ & $(0.010)$ & $(0.011)$ \\
& & & $0.022^{* * *}$ & $0.022^{* * *}$ \\
Competition & & & $(0.004)$ & $(0.004)$ \\
& & & & $0.047^{* * *}$ \\
Observations & & & & $(0.004)$ \\
Log likelihood & & & & 237,400 & 237,400 \\
& 237,400 & 237,400 & 237,400 & 237,400 & $-96,555$ \\
\hline
\end{tabular}


Table 2

\section{Data definitions}

\begin{tabular}{|c|c|c|}
\hline Variable & Variable Definition & Source \\
\hline Growth options & Growth in sales (sale) from $t-1$ to $t$ & Compustat \\
\hline Book debt & Debt in current liabilities (dlc) + long-term debt (dltt) & Compustat \\
\hline MB-ratio & $\begin{array}{l}\text { Market equity }(\text { csho }+ \text { prcc_f })+\text { Book debt }+ \\
\text { Preferred stock }(\text { pstk }) \\
\text { - Deferred taxes and investment tax credits } \\
(\text { txditc })) / \text { Assets total }(\text { at })\end{array}$ & Compustat \\
\hline Liquidation costs & $(1$ - Net PPE (ppent)) / Assets total (at) & Compustat \\
\hline Bargaining power & Fraction of stock owned by institutional investors & $\begin{array}{l}\text { Thomson } \\
\text { Reuter's }\end{array}$ \\
\hline Credit supply & $\begin{array}{l}(-1) * \text { Net percentage of banks tightening credit } \\
\text { standards to large and middle-market firms }\end{array}$ & $\begin{array}{l}\text { Federal } \\
\text { Reserve }\end{array}$ \\
\hline Competition & $\begin{array}{l}\text { Product market fluidity, available at } \\
\text { http://www.rhsmith.umd.edu/industrydata/ }\end{array}$ & Hoberg-Phillips \\
\hline Cash flow & $\begin{array}{l}\text { (Income before extraordinary items }(\mathrm{ib})+\text { depreciation } \\
\text { and amortization }(\mathrm{dp})) / \text { Assets total (at) }\end{array}$ & Compustat \\
\hline Volatility & $\begin{array}{l}\text { Annual standard deviation of cash flows over five } \\
\text { fiscal years (at least three consecutive obs.) }\end{array}$ & Compustat \\
\hline Size & Logarithm of net sales (sale) & Compustat \\
\hline Market leverage & $\begin{array}{l}\text { Book debt / (Market equity }+ \text { Assets total (at) - } \\
\text { Common equity (ceq)) }\end{array}$ & Compustat \\
\hline IG rating & $\begin{array}{l}\text { Dummy variable equal to one if the firm has an } \\
\text { investment grade rating and zero otherwise }\end{array}$ & Compustat \\
\hline Investment & $\begin{array}{l}\text { Capital expenditures (capx) / Assets total (at) at the } \\
\text { beginning of the fiscal year }\end{array}$ & Compustat \\
\hline Dividend dummy & $\begin{array}{l}\text { Dummy equal to one if the firm pays a dividend, zero } \\
\text { otherwise }\end{array}$ & Compustat \\
\hline Default probability & $\begin{array}{c}\text { Estimate of firm's default probability based on market } \\
\text { values following Bharath and Shumway (2008) }\end{array}$ & $\begin{array}{l}\text { Compustat- } \\
\text { CRSP }\end{array}$ \\
\hline E-Index & $\begin{array}{l}\text { Corporate governance index following Bebchuk, Cohen, } \\
\text { and Ferrell (2009) }\end{array}$ & L. Bebchuk \\
\hline Relation & $\begin{array}{l}\text { Number of relationship loans divided by the total } \\
\text { number of loans by firm }\end{array}$ & Dealscan \\
\hline
\end{tabular}


Table 3

Descriptive statistics

Table 3 presents descriptive statistics for the main variables used in the analysis. Panel A shows statistics for the firm-level variables. Panel B presents statistics for the macroeconomic and competition variables. The sample period is 1988-2007. Please refer to Table 2 for a detailed definition of the variables.

\begin{tabular}{|c|c|c|c|c|c|c|}
\hline \multicolumn{7}{|c|}{ Panel A: Firm-level variables } \\
\hline & Mean & S.D. & $25 \%$ & $50 \%$ & $75 \%$ & Obs \\
\hline Growth options (sales growth) & 0.162 & 0.504 & -0.013 & 0.086 & 0.218 & 49,063 \\
\hline MB-ratio & 1.529 & 1.362 & 0.786 & 1.111 & 1.743 & 49,063 \\
\hline Bargaining power in default & 0.456 & 0.289 & 0.205 & 0.451 & 0.684 & 36,811 \\
\hline Liquidation costs & 0.694 & 0.227 & 0.560 & 0.751 & 0.876 & 49,063 \\
\hline Investment & 0.076 & 0.092 & 0.025 & 0.049 & 0.092 & 49,063 \\
\hline Volatility & 0.077 & 0.106 & 0.020 & 0.039 & 0.085 & 49,063 \\
\hline Market leverage & 0.201 & 0.182 & 0.048 & 0.159 & 0.306 & 49,063 \\
\hline $\log ($ sales $)$ & 5.862 & 2.022 & 4.480 & 5.846 & 7.222 & 49,063 \\
\hline IG rating & 0.175 & 0.380 & 0.000 & 0.000 & 0.000 & 49,063 \\
\hline Cash flow & 0.048 & 0.168 & 0.030 & 0.080 & 0.125 & 49,063 \\
\hline Default probability & 0.189 & 0.309 & 0.000 & 0.004 & 0.266 & 43,256 \\
\hline Relation & 0.202 & 0.219 & 0.000 & 0.167 & 0.333 & 45,293 \\
\hline
\end{tabular}

Panel B: Macroeconomic and competition variables

\begin{tabular}{lrrrrrr}
\hline & Mean & S.D. & $25 \%$ & $50 \%$ & $75 \%$ & Obs \\
\hline Banks tightening lending (\%) & 6.295 & 20.166 & -9.075 & -0.275 & 19.625 & 46,569 \\
Product market fluidity & 6.601 & 3.257 & 4.195 & 6.028 & 8.400 & 27,337 \\
\hline
\end{tabular}




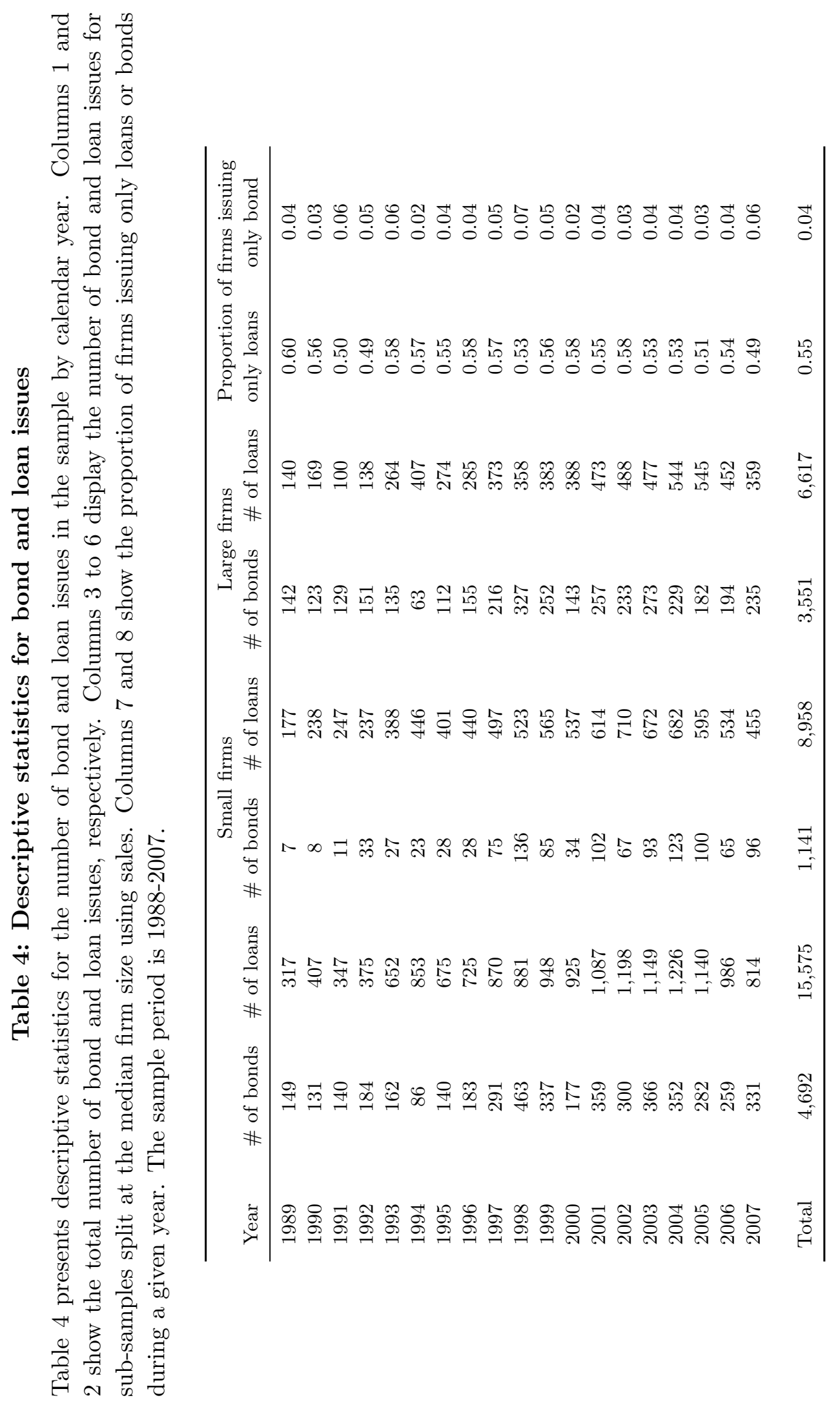


Table 5

\section{Debt choice logistic regressions: Main results}

Table 5 presents coefficient estimates from logistic regressions. The dependent variable is a dummy equal to one if a firm issues a bond and zero if a firm issues bank debt in a given month. Please refer to Table 2 for a detailed definition of the variables. The sample period is 1988-2007. All specifications include yearly dummies. The specifications in column 5 and 6 include FIC-300 industry fixed effects, and the specification in column 6 is estimated with random firm effects. Standard errors adjusted for heteroskedasticity and within-firm clustering are in parentheses below the coefficient estimates. The symbols ${ }^{* * *},{ }^{* *}$ and ${ }^{*}$ indicate statistical significance at the $1 \%, 5 \%$, and $10 \%$ levels, respectively.

\begin{tabular}{lcccccc}
\hline & $(1)$ & $(2)$ & $(3)$ & $(4)$ & $(5)$ & $(6)$ \\
\hline Growth options & $0.297^{* * *}$ & $0.415^{* * *}$ & $0.430^{* * *}$ & $0.352^{* * *}$ & $0.346^{* * *}$ & $0.367^{* * *}$ \\
& $(0.051)$ & $(0.066)$ & $(0.068)$ & $(0.078)$ & $(0.089)$ & $(0.075)$ \\
Bargaining power & & $0.917^{* * *}$ & $0.934^{* * *}$ & $0.645^{* * *}$ & $0.684^{* * *}$ & $0.681^{* * *}$ \\
& & $(0.158)$ & $(0.160)$ & $(0.185)$ & $(0.180)$ & $(0.201)$ \\
Credit supply & & & $-0.708^{* * *}$ & $-0.630^{* *}$ & $-0.643^{* *}$ & $-0.892^{* * *}$ \\
& & & $(0.253)$ & $(0.291)$ & $(0.304)$ & $(0.331)$ \\
Competition & & & & $0.087^{* * *}$ & $0.068^{* * *}$ & $0.075^{* * *}$ \\
& & & & $(0.012)$ & $(0.017)$ & $(0.019)$ \\
Volatility & -0.300 & 0.050 & 0.003 & -0.963 & 0.230 & 0.292 \\
& $(0.430)$ & $(0.497)$ & $(0.498)$ & $(0.605)$ & $(0.626)$ & $(0.714)$ \\
Market leverage & $3.099^{* * *}$ & $3.765^{* * *}$ & $3.827^{* * *}$ & $3.619^{* * *}$ & $3.233^{* * *}$ & $3.657^{* * *}$ \\
Size & $(0.200)$ & $(0.218)$ & $(0.220)$ & $(0.233)$ & $(0.257)$ & $(0.292)$ \\
& $0.321^{* * *}$ & $0.329^{* * *}$ & $0.324^{* * *}$ & $0.357^{* * *}$ & $0.359^{* * *}$ & $0.472^{* * *}$ \\
IG rating & $(0.026)$ & $(0.030)$ & $(0.031)$ & $(0.036)$ & $(0.037)$ & $(0.043)$ \\
& $0.747^{* * *}$ & $0.790^{* * *}$ & $0.775^{* * *}$ & $0.423^{* * *}$ & $0.351^{* * *}$ & $0.490^{* * *}$ \\
Constant & $(0.087)$ & $(0.089)$ & $(0.090)$ & $(0.106)$ & $(0.108)$ & $(0.125)$ \\
& $-4.448^{* * *}$ & $-5.303^{* * *}$ & $-5.281^{* * *}$ & $-5.597^{* * *}$ & $-5.559^{* * *}$ & $-6.962^{* * *}$ \\
Observations & $(0.220)$ & $(0.250)$ & $(0.254)$ & $(0.297)$ & $(0.443)$ & $(0.488)$ \\
Log likelihood & 14,536 & 11,662 & 11,340 & 7,521 & 7,089 & 7,380 \\
\hline
\end{tabular}


Table 6

\section{Debt choice logistic regressions: Robustness tests}

Table 6 presents coefficient estimates from logistic regressions. The dependent variable is a dummy equal to one if a firm issues a bond and zero if a firm issues bank debt in a given month. Column 1 includes an additional dummy variable equal to one if the firm pays a dividend, zero otherwise. Column 2 includes the E-Index as additional variable. Column 3 includes an interaction term between the default probability and shareholders' bargaining power in default. Column 4 contains an interaction term between growth options and a dummy variable for high competition (split at the median). Column 5 includes an additional variable controlling for existing banking relationships of firms. Finally, column 6 restricts the sample to years around investment spikes. In particular, it only considers bond and loan issues that are issued up to three years before to one year after an investment spike. Please refer to Table 2 for a detailed definition of the variables. The sample period is 1988-2007. All specifications include yearly dummies. Standard errors adjusted for heteroskedasticity and within-firm clustering are in parentheses below the coefficient estimates. The symbols $* * *, * *$ and $*$ indicate statistical significance at the $1 \%, 5 \%$, and $10 \%$ levels, respectively.

\begin{tabular}{|c|c|c|c|c|c|c|}
\hline & $(1)$ & $(2)$ & $(3)$ & $(4)$ & $(5)$ & $(6)$ \\
\hline Growth options & $\begin{array}{c}0.340^{* * *} \\
(0.080)\end{array}$ & $\begin{array}{c}0.402^{* *} \\
(0.173)\end{array}$ & $\begin{array}{c}0.309^{* * *} \\
(0.078)\end{array}$ & $\begin{array}{c}0.172 \\
(0.138)\end{array}$ & $\begin{array}{c}0.351^{* * *} \\
(0.063)\end{array}$ & $\begin{array}{c}0.534^{* * *} \\
(0.113)\end{array}$ \\
\hline Bargaining power & $\begin{array}{c}0.670^{* * *} \\
(0.188)\end{array}$ & $\begin{array}{c}0.439^{* *} \\
(0.209)\end{array}$ & $\begin{array}{c}0.281 \\
(0.216)\end{array}$ & $\begin{array}{c}0.560^{* * *} \\
(0.184)\end{array}$ & $\begin{array}{c}0.871^{* * *} \\
(0.137)\end{array}$ & $\begin{array}{c}0.432 \\
(0.418)\end{array}$ \\
\hline Credit supply & $\begin{array}{c}-0.668^{* *} \\
(0.294)\end{array}$ & $\begin{array}{c}-0.637^{*} \\
(0.354)\end{array}$ & $\begin{array}{c}-0.682^{* *} \\
(0.296)\end{array}$ & $\begin{array}{c}-0.645^{* *} \\
(0.289)\end{array}$ & $\begin{array}{c}-0.607^{* *} \\
(0.283)\end{array}$ & $\begin{array}{c}-1.437^{* *} \\
(0.720)\end{array}$ \\
\hline Competition & $\begin{array}{c}0.087^{* * *} \\
(0.013)\end{array}$ & $\begin{array}{c}0.059^{* * *} \\
(0.012)\end{array}$ & $\begin{array}{c}0.084^{* * *} \\
(0.012)\end{array}$ & & $\begin{array}{c}0.082^{* * *} \\
(0.009)\end{array}$ & $\begin{array}{c}0.133^{* * *} \\
(0.034)\end{array}$ \\
\hline Volatility & $\begin{array}{l}-0.820 \\
(0.608)\end{array}$ & $\begin{array}{l}-0.748 \\
(0.756)\end{array}$ & $\begin{array}{l}-0.201 \\
(0.586)\end{array}$ & $\begin{array}{l}-0.480 \\
(0.590)\end{array}$ & $\begin{array}{c}-1.047^{*} \\
(0.553)\end{array}$ & $\begin{array}{l}-1.787 \\
(1.191)\end{array}$ \\
\hline Market leverage & $\begin{array}{c}3.655^{* * *} \\
(0.236)\end{array}$ & $\begin{array}{c}3.557^{* * *} \\
(0.259)\end{array}$ & $\begin{array}{c}4.656^{* * *} \\
(0.326)\end{array}$ & $\begin{array}{c}3.720^{* * *} \\
(0.236)\end{array}$ & $\begin{array}{c}3.657^{* * *} \\
(0.181)\end{array}$ & $\begin{array}{c}4.473^{* * *} \\
(0.597)\end{array}$ \\
\hline Size & $\begin{array}{c}0.354^{* * *} \\
(0.037)\end{array}$ & $\begin{array}{c}0.324^{* * *} \\
(0.035)\end{array}$ & $\begin{array}{c}0.354^{* * *} \\
(0.037)\end{array}$ & $\begin{array}{c}0.362^{* * *} \\
(0.035)\end{array}$ & $\begin{array}{c}0.392^{* * *} \\
(0.026)\end{array}$ & $\begin{array}{c}0.372^{* * *} \\
(0.086)\end{array}$ \\
\hline IG rating & $\begin{array}{c}0.365^{* * *} \\
(0.108)\end{array}$ & $\begin{array}{c}0.412^{* * *} \\
(0.093)\end{array}$ & $\begin{array}{c}0.399^{* * *} \\
(0.109)\end{array}$ & $\begin{array}{c}0.407^{* * *} \\
(0.105)\end{array}$ & $\begin{array}{c}0.412^{* * *} \\
(0.084)\end{array}$ & $\begin{array}{c}0.653^{* *} \\
(0.308)\end{array}$ \\
\hline Dividend dummy & $\begin{array}{c}0.126 \\
(0.088)\end{array}$ & & & & & \\
\hline E-Index & & $\begin{array}{c}-0.033 \\
(0.029)\end{array}$ & & & & \\
\hline Default probability & & & $\begin{array}{c}-1.648^{* * *} \\
(0.336)\end{array}$ & & & \\
\hline $\begin{array}{l}\text { Bargaining power } \times \\
\text { Default probability }\end{array}$ & & & $\begin{array}{c}1.391^{* * *} \\
(0.511)\end{array}$ & & & \\
\hline High competition & & & & $\begin{array}{c}0.298^{* * *} \\
(0.081)\end{array}$ & & \\
\hline $\begin{array}{l}\text { Growth options } \times \\
\text { High competition }\end{array}$ & & & & $\begin{array}{c}0.302^{* *} \\
(0.153)\end{array}$ & & \\
\hline Relation & & & & & $\begin{array}{c}-0.701^{* * *} \\
(0.170)\end{array}$ & \\
\hline Constant & $\begin{array}{c}-5.661^{* * *} \\
(0.303)\end{array}$ & $\begin{array}{c}-4.869^{* * *} \\
(0.373)\end{array}$ & $\begin{array}{c}-5.413^{* * *} \\
(0.312)\end{array}$ & $\begin{array}{c}-5.180^{* * *} \\
(0.284)\end{array}$ & $\begin{array}{c}-6.036^{* * *} \\
(0.244)\end{array}$ & $\begin{array}{c}-6.724^{* * *} \\
(0.776)\end{array}$ \\
\hline $\begin{array}{l}\text { Observations } \\
\text { Log likelihood }\end{array}$ & $\begin{array}{c}7,416 \\
-3,820.21\end{array}$ & $\begin{array}{c}4,130 \\
-2,359.83\end{array}$ & $\begin{array}{c}7,202 \\
-3,748.13\end{array}$ & $\begin{array}{c}7,521 \\
-3,914.69\end{array}$ & $\begin{array}{c}7,229 \\
-3,549.89\end{array}$ & $\begin{array}{c}1,231 \\
-509.97\end{array}$ \\
\hline
\end{tabular}


Table 7

\section{Investment hazard model estimates: Main results}

Table 7 presents estimates from proportional hazard models for investment rates. An investment spike occurs in the data if the ratio of investment to total asset is two times greater than the firm median. Column 6 is estimated with FIC-300 industry fixed effects. Please refer to Table 2 for a detailed definition of the variables. The sample period is 1988-2007. Standard errors are in parentheses below the coefficient estimates. The symbols $* * *, * *$ and $*$ indicate statistical significance at the $1 \%, 5 \%$, and $10 \%$ levels, respectively.

\begin{tabular}{lcccccc}
\hline & $(1)$ & $(2)$ & $(3)$ & $(4)$ & $(5)$ & $(6)$ \\
\hline Growth options & $0.339^{* * *}$ & $0.350^{* * *}$ & $0.341^{* * *}$ & $0.344^{* * *}$ & $0.341^{* * *}$ & $0.373^{* * *}$ \\
Bargaining power & $(0.012)$ & $(0.016)$ & $(0.016)$ & $(0.021)$ & $(0.021)$ & $(0.023)$ \\
& & $-0.149^{* *}$ & $-0.180^{* *}$ & $-0.383^{* * *}$ & $-0.364^{* * *}$ & $-0.322^{* * *}$ \\
Credit supply & & $(0.068)$ & $(0.070)$ & $(0.092)$ & $(0.093)$ & $(0.100)$ \\
& & & $0.334^{* * *}$ & $0.208^{*}$ & $0.201^{*}$ & $0.284^{* *}$ \\
Competition & & $(0.087)$ & $(0.113)$ & $(0.113)$ & $(0.115)$ \\
& & & $0.022^{* * *}$ & $0.020^{* * *}$ & $0.036^{* * *}$ \\
Liquidation costs & & & $(0.007)$ & $(0.007)$ & $(0.010)$ \\
& & & & $-0.543^{* * *}$ & $-1.167^{* * *}$ \\
Volatility & & & & $(0.1)$ & $(0.136)$ \\
& 0.167 & 0.054 & 0.054 & -0.103 & 0.026 & 0.046 \\
Market leverage & $(0.129)$ & $(0.172)$ & $(0.174)$ & $(0.221)$ & $(0.223)$ & $(0.233)$ \\
Size & $-0.176^{* *}$ & $-0.251^{* * *}$ & $-0.269^{* * *}$ & -0.209 & $-0.452^{* * *}$ & $-0.555^{* * *}$ \\
Cash flow & $(0.074)$ & $(0.094)$ & $(0.098)$ & $(0.130)$ & $(0.139)$ & $(0.152)$ \\
& $-0.138^{* * *}$ & $-0.133^{* * *}$ & $-0.137^{* * *}$ & $-0.166^{* * *}$ & $-0.166^{* * *}$ & $-0.189^{* * *}$ \\
Constant & $(0.007)$ & $(0.011)$ & $(0.011)$ & $(0.016)$ & $(0.016)$ & $(0.018)$ \\
& $0.974^{* * *}$ & $0.975^{* * *}$ & $0.967^{* * *}$ & $1.071^{* * *}$ & $0.940^{* * *}$ & $1.159^{* * *}$ \\
Observations & $(0.089)$ & $(0.114)$ & $(0.116)$ & $(0.146)$ & $(0.146)$ & $(0.155)$ \\
Log likelihood & $-2.028^{* * *}$ & $-2.073^{* * *}$ & $-2.016^{* * *}$ & $-1.801^{* * *}$ & $-1.363^{* * *}$ & $-0.804^{* *}$ \\
\hline & $(0.220)$ & $(0.253)$ & $(0.254)$ & $(0.271)$ & $(0.283)$ & $(0.337)$ \\
& 49063 & 36811 & 35051 & 22115 & 22115 & 21935 \\
& -16642.02 & -11948.29 & -11113.18 & -6338.542 & -6324.124 & -6021.71 \\
\hline
\end{tabular}


Table 8

\section{Investment hazard model estimates: Robustness tests}

Table 8 presents estimates from proportional hazard models for investment rates. An investment spike occurs in the data if the ratio of investment to total asset is two times greater than the firm median. Column 1 includes an additional dummy variable equal to one if the firm pays a dividend, zero otherwise. Column 2 includes the E-Index as additional variable. Column 3 includes the default probability as additional control variable. In column 4 , the threshold for an investment spike is three times the median. Columns 5 and 6 estimate the proportional hazard model with unobserved heterogeneity (frailty). In column 5, we assume that unobserved heterogeneity is normally distributed, whereas in column 6 we assume that it is gamma distributed. Please refer to Table 2 for a detailed definition of the variables. The sample period is 1988-2007. $\rho$ is the ratio of the het-

erogeneity variance to one plus the heterogeneity variance. $\sigma^{2}$ is the estimate of the heterogeneity variance. Standard errors are in parentheses below the coefficient estimates. The symbols ***, ** and ${ }^{*}$ indicate statistical significance at the $1 \%, 5 \%$, and $10 \%$ levels, respectively.

\begin{tabular}{|c|c|c|c|c|c|c|}
\hline & $(1)$ & $(2)$ & $(3)$ & $(4)$ & $(5)$ & $(6)$ \\
\hline Growth options & $\begin{array}{c}0.364^{* * *} \\
(0.021)\end{array}$ & $\begin{array}{c}0.704^{* * *} \\
(0.093)\end{array}$ & $\begin{array}{c}0.332^{* * *} \\
(0.022)\end{array}$ & $\begin{array}{c}0.357^{* * *} \\
(0.027)\end{array}$ & $\begin{array}{c}0.435^{* * *} \\
(0.038)\end{array}$ & $\begin{array}{c}0.458^{* * *} \\
(0.043)\end{array}$ \\
\hline Bargaining power & $\begin{array}{c}-0.377^{* * *} \\
(0.093)\end{array}$ & $\begin{array}{c}-0.830^{* *} \\
(0.413)\end{array}$ & $\begin{array}{c}-0.363^{* * *} \\
(0.100)\end{array}$ & $\begin{array}{c}-0.667^{* * *} \\
(0.146)\end{array}$ & $\begin{array}{c}-0.104 \\
(0.127)\end{array}$ & $\begin{array}{l}-0.100 \\
(0.125)\end{array}$ \\
\hline Credit supply & $\begin{array}{c}0.244^{* *} \\
(0.113)\end{array}$ & $\begin{array}{c}0.162 \\
(0.474)\end{array}$ & $\begin{array}{c}0.175 \\
(0.121)\end{array}$ & $\begin{array}{c}0.331^{*} \\
(0.175)\end{array}$ & $\begin{array}{c}0.277^{* *} \\
(0.139)\end{array}$ & $\begin{array}{c}0.309 * * \\
(0.136)\end{array}$ \\
\hline Competition & $\begin{array}{c}0.016^{* *} \\
(0.007)\end{array}$ & $\begin{array}{l}0.052^{*} \\
(0.027)\end{array}$ & $\begin{array}{l}0.013^{*} \\
(0.007)\end{array}$ & $\begin{array}{c}0.033^{* * *} \\
(0.011)\end{array}$ & $\begin{array}{c}0.019^{*} \\
(0.010)\end{array}$ & $\begin{array}{c}0.019^{*} \\
(0.010)\end{array}$ \\
\hline Liquidation costs & $\begin{array}{c}-0.606^{* * *} \\
(0.101)\end{array}$ & $\begin{array}{c}-1.251^{* * *} \\
(0.385)\end{array}$ & $\begin{array}{c}-0.523^{* * *} \\
(0.104)\end{array}$ & $\begin{array}{c}-0.670^{* * *} \\
(0.151)\end{array}$ & $\begin{array}{c}-0.840^{* * *} \\
(0.152)\end{array}$ & $\begin{array}{c}-0.864^{* * *} \\
(0.155)\end{array}$ \\
\hline Volatility & $\begin{array}{c}0.114 \\
(0.224)\end{array}$ & $\begin{array}{c}-0.139 \\
(0.951)\end{array}$ & $\begin{array}{c}0.036 \\
(0.244)\end{array}$ & $\begin{array}{c}0.547^{*} \\
(0.301)\end{array}$ & $\begin{array}{l}-0.237 \\
(0.323)\end{array}$ & $\begin{array}{l}-0.255 \\
(0.316)\end{array}$ \\
\hline Market leverage & $\begin{array}{c}-0.447^{* * *} \\
(0.139)\end{array}$ & $\begin{array}{l}-0.931 \\
(0.655)\end{array}$ & $\begin{array}{l}-0.050 \\
(0.207)\end{array}$ & $\begin{array}{c}-0.484^{* *} \\
(0.212)\end{array}$ & $\begin{array}{c}-0.715^{* * *} \\
(0.189)\end{array}$ & $\begin{array}{c}-0.714^{* * *} \\
(0.184)\end{array}$ \\
\hline Size & $\begin{array}{c}-0.158^{* * *} \\
(0.016)\end{array}$ & $\begin{array}{c}-0.253^{* * *} \\
(0.069)\end{array}$ & $\begin{array}{c}-0.180^{* * *} \\
(0.017)\end{array}$ & $\begin{array}{c}-0.188^{* * *} \\
(0.024)\end{array}$ & $\begin{array}{c}-0.204^{* * *} \\
(0.023)\end{array}$ & $\begin{array}{c}-0.200^{* * *} \\
(0.023)\end{array}$ \\
\hline Cash flow & $\begin{array}{c}0.965^{* * *} \\
(0.147)\end{array}$ & $\begin{array}{c}1.190^{*} \\
(0.713)\end{array}$ & $\begin{array}{c}0.769^{* * *} \\
(0.156)\end{array}$ & $\begin{array}{c}0.833^{* * *} \\
(0.197)\end{array}$ & $\begin{array}{c}1.478^{* * *} \\
(0.206)\end{array}$ & $\begin{array}{c}1.444^{* * *} \\
(0.201)\end{array}$ \\
\hline Dividend dummy & $\begin{array}{c}-0.131^{* *} \\
(0.057)\end{array}$ & & & & & \\
\hline E-Index & & $\begin{array}{l}-0.068 \\
(0.071)\end{array}$ & & & & \\
\hline Default probability & & & $\begin{array}{c}-0.493^{* * *} \\
(0.139)\end{array}$ & & & \\
\hline Constant & $\begin{array}{c}-1.331^{* * *} \\
(0.292)\end{array}$ & $\begin{array}{l}-1.338 \\
(1.026)\end{array}$ & $\begin{array}{c}-1.201^{* * *} \\
(0.287)\end{array}$ & $\begin{array}{c}-2.188^{* * *} \\
(0.488)\end{array}$ & $\begin{array}{c}-1.763^{* * *} \\
(0.623)\end{array}$ & $\begin{array}{c}-1.268^{* *} \\
(0.629)\end{array}$ \\
\hline$\rho$ & & & & & $\begin{array}{c}0.314^{*} \\
(0.171)\end{array}$ & \\
\hline$\sigma^{2}$ & & & & & & $\begin{array}{c}0.169 \\
(0.162)\end{array}$ \\
\hline Observations & 21,897 & 9,273 & 20,040 & 22,115 & 21,813 & 21,813 \\
\hline Log likelihood & $-6,254.28$ & -612.72 & $-5,662.25$ & $-3,312.62$ & $-5,489.63$ & $-5,491.17$ \\
\hline
\end{tabular}


Figure 1. Ratio of optimal investment triggers.

Figure 1 plots the ratio of the investment triggers $z \equiv \bar{X}_{B}^{*} / \bar{X}_{D}^{*}$ as a function of the arrival rate of informed lenders $\delta$, the bargaining power of shareholders in default $\eta$, the size of the growth option $\pi$, cash flow volatility $\sigma$, liquidation $\operatorname{costs} \alpha$, and the arrival rate of competitors $\lambda$. Parameter values are set as in the base case environment.
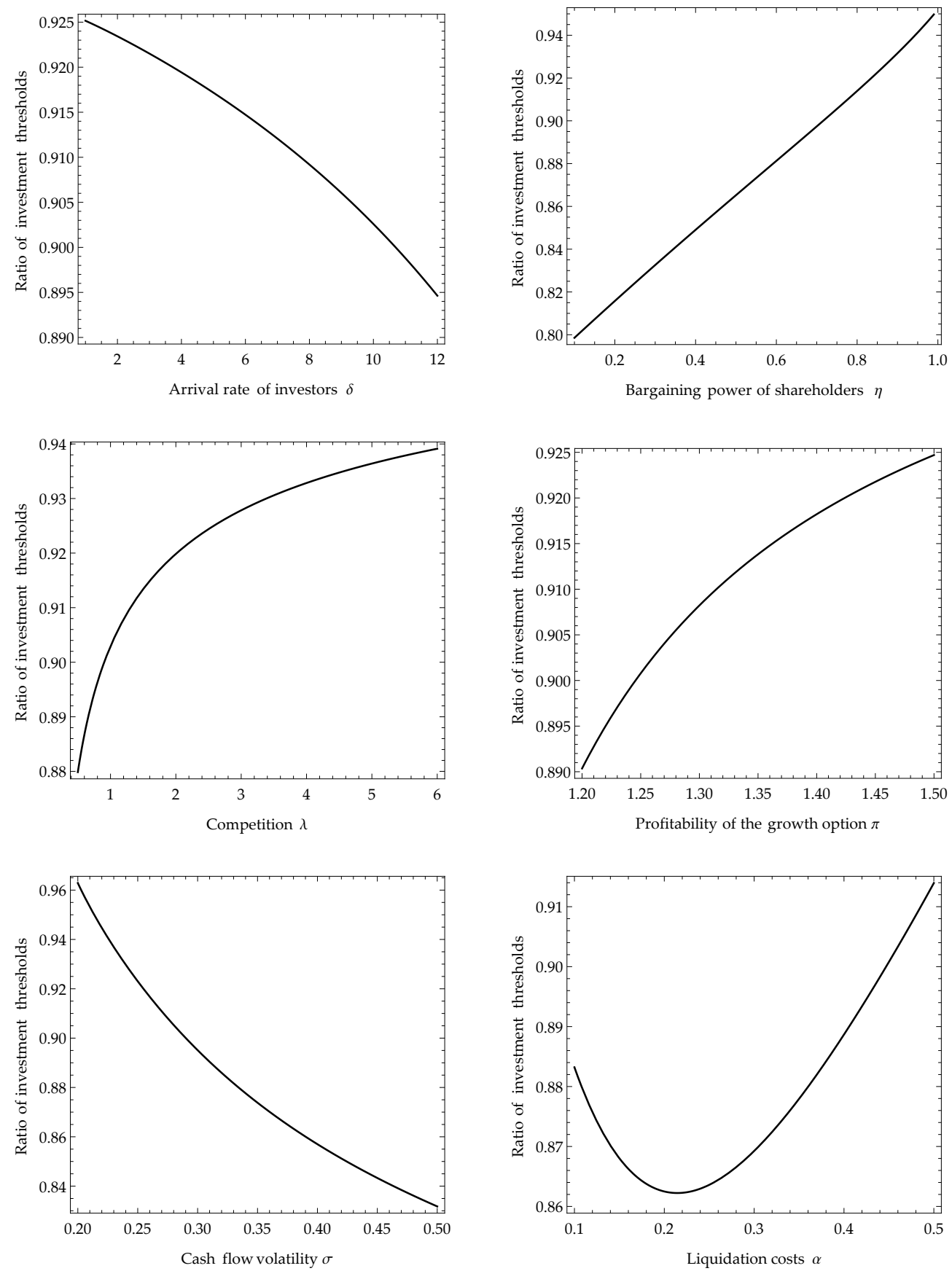
Figure 2. Credit lines.

The top 4 panels plot the relative value of equity, defined as the value of equity when using public debt over the value of equity when using a credit line (i.e. $E_{1}\left(X ; c^{*}\right) / E_{1}\left(X ; \ell^{*}\right)$ ), as a function of the profitability of the growth option $\pi$, the volatility of cash flows $\sigma$, the bargaining power of shareholders in default $\eta$, and bankruptcy $\operatorname{costs} \alpha$. The bottom 2 panels the ratio of the investment triggers $z \equiv \bar{X}_{B}^{*} / \bar{X}_{1, \ell}^{*}$ as a function of the arrival rate of informed lenders $\delta$ and the bargaining power of shareholders at the time of investment $\theta$.
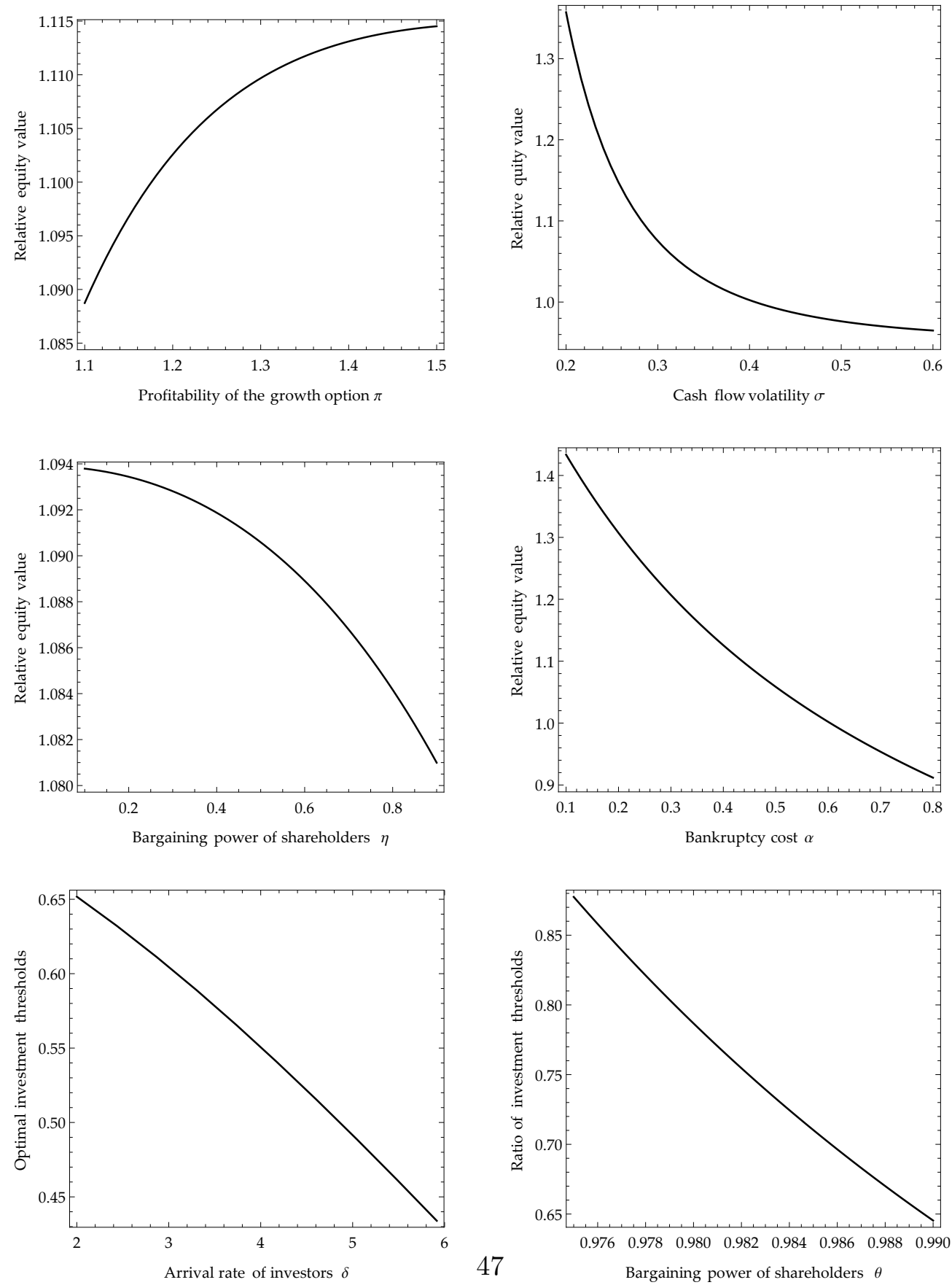